\title{
COVID-19 Haberlerinde Siyasi Kutuplaşmanın Yansımaları: Hürriyet ve Gazete Pencere Üzerine Bir İnceleme
}

\section{Turancan Şirvanlı}

\section{Öz}

Bu çalışmada, Türkiye'yi etkisi altına alan COVID-19 pandemi sürecinin alternatif ve ana akım basında, siyasi kutuplaşma kavramından hareketle ne ölçüde ve nasıl sunulduğunun araştırılması amaçlanmıştır. COVID-19 pandemisi halk sağlığını ilgilendiren bir mesele olduğu için, sürece ilişkin üretilen haber metinlerinin gazetelerin siyasi yönelimlerinden bağımsız olması beklenmektedir. Bu bağlamda, çalışmada araştırma nesnesi olarak ideolojik yönelimi görece "merkez medya" konumundaki iki gazete seçilmiştir. Ekonomi politik anlamda ana akım ve alternatif medya olarak tanımlanabilecek iki farklı gazete olan Hürriyet ve Gazete Pencere, nicel ve nitel analiz yöntemleri kullanılarak incelenmiştir. Araştırma sonuçlarına göre, Gazete Pencere, COVID-19'a ilişkin haberleri daha çok "Vaka ve ölüm sayılarının doğru verilmemesi" ve "Devlet yetkililerinin kısıtlamalara uymaması" konuları üzerinden çerçevelerken, Hürriyet gazetesi COVID-19 haberlerini, "yurttaşların tedbirlere uymaması" ekseninde yansıtmaktadır. Bu durum, Türkiye'deki iktidar ve muhalefet kanadındaki aktörlerin argümanları ile uyumluluk taşımaktadır. Aynı zamanda iki gazetede de politikacıların bilim insanlarından daha sık yer aldığı görülmektedir. Çalışmada, kutuplaşmış politik ve toplumsal alandaki güç ve iktidar mücadelesinin -sağlık konusu ön planda olmasına ve gazetelerin görece merkez medya konumlarına rağmen- medya alanında da kendisini gösterdiği sonucuna ulaşılmıştır.

Anahtar Sözcükler: COVID-19, Kutuplaşma, Ana Akım Medya, Alternatif Medya, Siyasallaşma

\author{
TURANCAN ŞIRVANLI \\ Arş. Gör \\ Kocaeli Üniversitesi \\ turancan.sirvanli@kocaeli.edu.tr \\ ORCID ID: 0000-0002-7286-3070
}

SELÇUK ILETIŞIM DERGISI 2021; 14(2): 1005-1038

doi: 10.18094/ JOSC.883597

Geliş Tarihi: 20.02.2021 Kabul Tarihi: 31.03.2021 Yayın Tarihi: 25.04.2021 
Reflections of Political Polarization in COVID-19 News: A Study on Hürriyet and Gazete Pencere
JOURNAL OF SELÇUK COMMUNICATION 2021;

14(2): 1005-1038

doi: 10.18094/ JOSC.883597

\title{
Turancan Şirvanlı
}

\begin{abstract}
In this study, it is aimed to investigate the what extent and how the COVID-19 pandemic process is presented in Turkey's mainstream and alternative press based on the concept of political polarization. The COVID-19 pandemic is an issue that concerns public health. Therefore, news texts about COVID-19 are expected to be independent of the political orientation of newspapers. In this context, two newspapers whose political orientations are relatively "central media" were selected as research objects in this study. Hürriyet and Gazete Pencere, two different newspapers that can be defined as mainstream and alternative media in the political economy context, were analyzed using quantitative and qualitative analysis methods. According to the results of the research, Gazete Pencere frames the news about COVID-19 mostly on the subjects of "not giving the correct number of cases and deaths" and "state officials' failure to comply with measures", while Hürriyet reflects the COVID-19 news on the axis of "citizens' failure to comply with the measures". This situation is compatible with the arguments of the ruling and opposition actors in Turkey. At the same time, it is seen that politicians appear more frequently than scientists in both newspapers. In this study, it was concluded that the power and struggle in the polarized political and social sphere -despite the fact that health is at the forefront and newspapers are relatively central media- also manifested itself in the media field.
\end{abstract}

Keywords: COVID-19, Polarization, Mainstream Media, Alternative Media, Politicization

\section{TURANCAN ŞIRVANLI}

Res. Asst

Kocaeli University

turancan.sirvanli@kocaeli.edu.tr

ORCID ID: 0000-0002-7286-3070

JOURNAL OF SELÇUK COMMUNICATION 2021; 14(2): 1005-1038

doi: $10.18094 /$ JOSC.883597 


\section{GiRiş}

2020 yılında tüm dünya yeni bir virüs türü olan COVID-19 (koronavirüs) salgınıyla karşı karşıya kalmıştır. Dünya Sağıı Örgütü 30 Ocak 2020 tarihinde acil durum ilan ettikten sonra, 11 Mart 2020'de salgının pandemi ${ }^{1}$ olduğunu açıklamıştır. Koronavirüs pandemisi, Türkiye'yi de etkilemiş; 11 Mart 2020'de Türkiye'deki ilk koronavirüs vakası Sağlık Bakanı Fahrettin Koca tarafından açıklanmıştır. Süreç içinde Türkiye'deki vaka ve ölüm sayıları artmış, 8 Nisan 2020'de ilk kez bir günde dört binden fazla yeni vaka tespit edilmiştir (Yücel, 2020).

COVID-19 önemli bir risk oluştururken, Türkiye medyası da konuya ilişkin çeşitli haberler yapmış ve resmi yetkililerin açıklamalarını kamuoyuna sunmuştur. Ancak, koronavirüs gibi halk sağlığını ilgilendiren meselelere ilişkin haberlerin "nasıl sunulduğu", üzerinde durulması gereken bir konu olarak görülmektedir. Sağlık haberleri kamuoyunu ilgilendiren kitlesel bir meseledir. Günlük rutin haberlerden farklı olarak çoğunluğu ilgilendirecek şekilde bir bilgi aktarıyor olması beklenir (Öğüt, 2013, s. 59). çünkü, sağlık haberleri, toplumu "bilgilendirme ve duyurma" amaçlı işlev üstlenmektedir (Utma, 2017, s. 598). Bu açıdan, sağlık haberlerinin ekonomik, politik ve ideolojik kaygılardan uzak, evrensel bir çerçevede kurulması önem taşımaktadır.

Dolayısıyla, tüm dünyayı olduğu gibi Türkiye'yi de etkisi altına alan koronavirüs pandemisinin yaşandığı günümüzde, koronavirüse ilişkin üretilen haberlerin (özünde tüm haber metinlerinin), medya kuruluşlarının politik yönelimlerinden bağımsız olması beklenir. Bu bağlamda, hem politik aktörlerin hem de medyanın COVID-19'a ilişkin enformasyonu nasıl ve hangi bağlamda aktardığı önemli bir konudur. Çünkü, medyanın haberleri çerçeveleme biçimi siyasal bölünmeleri şiddetlendirebilir, sosyal hayatı şekillendirebilir ve politik kutuplaşmayı artıracak şekilde halkın tutumlarını etkileyebilmektedir (Bolsen, Druckman, \& Cook, 2014; Carpini, 2004; Scheufele, 1999; Entman, 1993). Ayrıca, medyanın sunduğu bu çerçeveler kitlelerin tutumlarını etkileyebileceği gibi; kitlelerin politik yönelimleri de medya gruplarının yayın politikalarının şekillenmesinde etkili olabilmektedir (Vona Kurt, 2015, s. 203).

Buna ek olarak, medya gruplarının ekonomi politiği de -yayıncılık anlayışındaki belirleyici özelliğinden dolayı- sosyal gerçekliğin yaratılmasında/sürdürülmesinde önemli bir noktadadır. Medya

\footnotetext{
'Pandemi, dünyada birden fazla ülkede veya kıtada, çok geniş bir alanda yayılarak etkisini gösteren salgın hastalıklara verilen genel isimdir (WHO, 2010).
} 
yapılanmalarının içinde bulunduğu üretim ilişkileri, kitle iletişiminin ideolojik boyutunu göstermekle birlikte; toplumdaki ekonomik ve politik yapılar hakkında fikirlerin yayılmasında etkin bir rol oynamaktadır (Murdock \& Golding, 1973, s. 206-207). Dolayısıyla, siyasi kutuplaşmanın farklı nedenlerle ortaya çıkan, farkı örüntüleri olduğu söylenebilir. Bu örüntüleri, ana akım medya ve alternatif medya gibi farklı ekonomi politik dinamiklere sahip medya organlarının haber metinlerinde aramak, tartışmaya açılması gereken bir konu olarak görülmektedir. Dolayısıyla, bu çalışmanın konusu, "Türkiye'de ana akım ve alternatif medyada koronavirüse ilişkin haberlerin siyasi kutuplaşma bağlamında ne ölçüde ve nasıl sunulduğu"dur.

Bu çalışmada, 2020 Ağustos ve Eylül ayları içinde koronavirüs pandemisinin Türkiye ana akım ve alternatif basınındaki haberlerde, siyasi kutuplaşmadan hareketle nasıl kurulduğunun; haberlerde bilim insanları ile siyasi aktörlerin nasıl ve ne sıklıkla temsil edildiğinin araştırılması amaçlanmaktadır. Bu amaçlardan hareketle, çalışmada hem ekonomi politik bağlamda hem de mecra olarak farklılık gösteren ve siyasi yönelimleri görece "merkezde" kabul edilen iki gazete incelenmiştir. Türkiye basınının "amiral gemisi" olarak tanımlanan (Özkır, 2013, s. 61) ve ana akım medyada önemli bir konumda bulunan Hürriyet gazetesi birinci araştırma nesnesi olarak seçilirken; alternatif medya olarak tanımlanabilecek bağımsız bir yayın olan Gazete Pencere ikinci araştırma nesnesi olarak tercih edilmiştir. Bu bağlamda, çalışma boyunca şu araştırma sorularının cevapları aranmıştır:

AS1- Ana akım ve alternatif medya arasında koronavirüs haberlerini ele alış şekli ve oranı bakımından ne gibi farklııklar vardır?

AS2- İlgili gazetelerdeki koronavirüs haberlerinde bilim insanlarının temsil oranlarıyla siyasi liderlerin temsil oranları nelerdir? Koronavirüs haberlerindeki aktörler nasıl bir bağlamda sunulmuşlardır?

AS3- Illgili gazeteler koronavirüs haberlerinden hareketle politik kutuplaşmayı nasıl yansıtmakta ve politik kutuplaşmanın yeniden üretimine nasıl bir katkı sunmaktadır?

Bu çalışmanın araştırma soruları, test etmek (betimlemek) ve anlamak (yorumlamak) üzerine kurulduğu için çalışmada hem nicel hem de nitel araştırma yöntemlerini kapsayan karma bir yöntem kullanılmıştır. Bu bağlamda, nicel içerik analizi tekniği ile, gazetelerin ilk sayfalarında koronavirüse ilişkin haberlere ne sıklıkta ve hangi bağlamda yer verdikleri; ne kadar yazı ve fotoğraf/grafik alanı ayırdıkları; siyasetçilere ve bilim insanlarına ne sıklıkta ve hangi bağlamda (destekleyici, nötr, olumsuz) yer ayırdıkları 
incelenmiştir. Buna ek olarak, daha bütüncül bulgulara ulaşabilme adına haber metinleri, nitel içerik analizi ile incelenmiştir. Araştırmada gazetelerin koronavirüs pandemi sürecine ilişkin temel yaklaşımları, politik kutuplaşma kavramsal çerçevesinden hareketle ortaya konulmaya çalışılmıştır. Bu haberler aracılığıyla okurlara iletilmek istenen anlamlarla birlikte, gazetelerin haber metinlerinde politik kutuplaşmaya ne ölçüde ve nasıl katkı sunduğu incelenmiştir.

COVID-19 haber metinlerini betimlemek ve metinlerdeki söylem boyutunu yorumlamak üzere gerçekleştirilen analizlerin sonucunda, politikacıların haberlerde bilim insanlarından daha sık yer aldığı; iki gazetede de siyasallaşma ve kutuplaşma adına önemli örüntülerin bulunduğu; Gazete Pencere'nin sürece ilişkin daha fazla haber yaptığı ve COVID-19'a ilişkin haberleri "Vaka ve ölüm sayılarının doğru verilmemesi" ve "Devlet yetkililerinin kısıtlamalara uymaması" gibi konular üzerinden verdiği, Hürriyet gazetesinin ise "yurttaşların tedbirlere uymaması" çerçevesinde bir sunum gerçekleştirdiği bulgularına ulaşılmıştır.

\section{SAĞLIK HABERCiLiǦíniN ELEŞTiREL BIR DEĞERLENDIRMESi}

Kutuplaşma ve COVID-19 haberleri üzerinden politik kutuplaşma ilişkisini tartışmadan önce, eleştirel bir perspektifle sağık haberciliğinin genel çerçevesine değinmek anlamlı görülmektedir. Bu bağlamda, kutuplaşmaya ilişkin örüntüleri, sağlık haberciliğinin ekonomi politik unsurlarından hareketle değerlendirmek daha bütüncül bir tablo sunacaktır. Sağlık haberciliğine ve bir haberi sağlık haberi yapan ölçütlerin ne olduğuna yönelik tanımlamalar, 1990'ı yıllardaki çalışmalara kadar muğlak bir zeminde ilerlemiş̧tir. Bu anlamda sağlık haberciliği, daha genel geçer ifadelerle tanımlanmıştır. En genel anlamıyla insan sağ|ı̆̆ını ve yaşam kalitesini ilgilendiren her türlü habercilik faaliyeti sağlık haberciliği içinde değerlendirilmektedir (Öğüt, 2013, s. 33). Sağlık haberlerinin insanları sağlık konusunda bilgilendirmek, farkındalık yaratmak, bilinçlendirmek ve uyarmak gibi işlevleri bulunmaktadır (Utma, 2017, s. 598). Halka yönelik ve sağlık profesyonellerine yönelik olmak üzere iki temel alanda gerçekleştirilen sağık haberciliği ele aldığı konu, dil ve üslup bakımından bu iki alanda farklılık göstermektedir. Bu anlamda, özellikle dergi yayıncılığında gözlenen sağlık profesyonellerine yönelik sağlık haberlerinde daha bilimsel bir dil kullanıldığı söylenebilir (Ögüt, 2013, s. 37). Sağlık haberlerinin üretim pratikleri, haberlerin üretildiği dönemin medya atmosferine bağlı olarak değişiklik göstermektedir. 
Türkiye'de 1970'li ve 1980'li yıllarda sadece "normal dışı" olayların sansasyonel anlatımıyla verilen sağık haberleri, 1990 'ı ve 2000 'li yıllarda deneyimli sağlık muhabirlerinin istihdam edilmesiyle daha profesyonel bir zemine oturmuştur (Ögüt, 2013, s. 138). Sağlık haberciliğinin bir uzmanlık alanı olarak görülmeye başlanmasında, 1991 yılında Eğitim ve Sağlık Muhabirleri Derneği'nin (ESAM-DER) kurulması etkili olmuş ve dernek tarafından alana yönelik belirli ilkeler ortaya konulmaya çalışıımıştır. 1990'lı ve 2000'li yıllarda sağlık konulu yayınların artışı dikkat çekicidir. Alandaki profesyonelleşme ile birlikte radyo ve televizyonlarda sağlık konulu programlar yapılmaya başlanmış, İnternette sağık özelinde sayfalar görünürlük kazanmıştır (Yüksel, Kaya, Koçak, \& Aydın, 2010, s. 19). Ancak, ekonomi politik bağlamda değerlendirildiğinde, yayınlardaki nicel artışın dinamiğini kamu yararından çok ticari çıkarların belirlediği söylenebilir.

Bu noktada, sağlık haberlerinin üretim koşullarını anlamak için genel anlamda ana akım medya sektöründe gerçekleşen yapısal değişimlere değinmek yerinde olacaktır. 1980 sonrası dünyada ve Türkiye'de uygulanan neoliberal politikalar medya alanını değiş̧irmiş/dünüştürmüş ve buna bağlı olarak haber içerikleri ve haberlerin bağlamı da değişmiş/dönüşmüştür. ${ }^{2}$ Bu değişimin güdüleyici dinamiğini ana akım medya alanındaki yoğunlaşma, yöndeşme ve çapraz tekelleşme eğilimleri oluşturmuştur (Dağtaş, 2006, s. 122). Dolayısıyla bu dönemi, medyada şirketleşme (ticarileşme) ve buna bağlı olarak haberlerin metalaşması bağlamında okumak daha doğru olacaktır. Sağlık haberciliğini de bu eksende değerlendirmek geçmişte ve günümüzde haberler üzerinden kurulan egemen ilişkileri anlamak adına önemlidir.

Özel televizyonlarla birlikte özel hastanelerin de sayısının artması, kurumlar arası kurulacak ticari ilişkilerin önünü açmıştır. Bu bağlamda, özel hastanelerin kurumsal iletişim birimleri ile sağlık muhabirlerinin kurmuş olduğu ilişki, kurumsal iletişim kaynaklı bir sağlık iletişimi pratiğini gün yüzüne çıkarmıştır. Birbirinden ayrı tutulması gereken kurumsal iletişim ve gazetecilik alanlarının yöndeşmesi, sağlık haberlerinin bir örtülü reklam aracı olarak kullanılmasına neden olmuştur. Kuşkusuz, haber-meta içeriklerin yaygınlık kazanması sadece gazetecilerin tercihlerinden ya da sağlık haberciliği alanındaki profesyonelleşememeden kaynaklı değildir; medya sahipliği ve çapraz tekelleşme eğilimlerine bağlı

\footnotetext{
21980 öncesinde de ana akım medyanın çeşitli yapısal sorunları bulunmaktadır (Koloğlu, 1992, s. 86-87). Ancak, günümüzdeki medya atmosferini şekillendiren temel gelişmenin, 1980 sonrası dünyada ve Türkiye'de uygulanmaya başlanan yeni sağ politikalar olduğu söylenebilir (Sönmez, 2004, s. 40).
} 
olarak medyadaki ekonomik örgütlenme modeli, içeriklerdeki erozyonun temelini oluşturmaktadır. 1980 sonrası başlayan ve Türkiye'de kapitalizmin yeniden yapılanma sürecinin ilk adımı olarak kabul edilen bu dönem, medya kurumlarının kamu hizmeti anlayışından uzaklaşıp sermaye çıkarı odaklı bir yayın politikası benimsemeleri ile devam etmiştir (Dağtaş, 2006, s. 66). Dolayısıyla, haber-meta olarak inşa edilen sağlık haberleri, aynı zamanda toplumdaki egemen güç ve iktidar ilişkilerinin yeniden üretildiği bir alan olarak değerlendirilebilir.

Konu, günümüzdeki ana akım medyanın sektörel dinamikleri bağlamında tartışıldığında, yayın gruplarının ekonomi politik yapılarının, sağlık haberlerinin inşa edildiği çerçeveyi belirlemeye devam ettiği söylenebilir. "Kamu yararının en çok gözetilmesi gereken alanlardan biri olan sağlık haberciliğinde, medyanın haberi çerçeveleme ve sunma biçimi toplumun değil medyaya sahip olan sermaye gruplarının temsil ettiği çıkar merkezlerinin lehine işletilmektedir" (Taylan \& Ünal, 2017, s. 28). Buna bağlı olarak ana akım medyaya yerleşmiş olan sansasyonel ve magazinel habercilik refleksi, sağılık haberciliği alanında da kendisini göstermektedir. Özellikle, haber bültenlerinin magazinleşmesi sağlık haberlerinin ele alınış biçimini de etkilemektedir. Çünkü, genel anlamda magazin haberleri bilgilendirmekten çok, hoşça vakit geçirmek, oyalanmak ve gündelik hayattan belirli ölçüde kopmak üzere üretilmektedir (Dağtaş, 2006, s. 101). Magazinel içerikler, tüketim kültürünü öncelediği için sağlık haberlerinin önemli bir bölümü "uzun yaşam reçeteleri, diyet önerileri, anti-aging, fitness, estetik ameliyatlar"3 gibi içerikler ekseninde çerçevelenmekte ve haberlerde orta, üst sınıflara özgü bir yaşam tarzı sunulmaktadır (Gür, 2009; Birsen \& Öztürk, 2011).

Dolayısıyla, reklam ya da ürün tanıtımı olarak değerlendirilebilecek içeriklerin sağlık haberleri olarak sunulması, birçok sağılı haberinin kamusal yararı değil, ticari kaygıları öncelediğini göstermektedir (Taylan \& Ünal, 2017, s. 33). Öyle ki, Erkan Yüksel vd.'nin Türkiye'deki sağlık konulu yayınlara yönelik TÜBITAK projesi kapsamında gerçekleştirdikleri bir çalışmada, "haber konusu, kaynak, konuk seçiminde reklam ya da sponsorluk baskısı ya da ticari kaygı hissedilmesi konusundaki soruya görüşuilen sağlık profesyonellerinin \%91'i, medya profesyonellerinin ise \%58'i "Evet, kesinlikle var" yanıtını vermiştir.

\footnotetext{
${ }^{3}$ Sağılk haberlerinin, özellikle kadınlar ve kadın bedeni üzerinden bu şekilde sunumu, kadın bedenini metalaştırmaktadır. Çünkü, özellikle estetik ameliyatı temalı sağlık haberleri, tüketim kültürünün bir gerekliliği olan "ideal beden" tipolojisi üzerinden ilerlemektedir. Ataerkil kapitalist sistemde cinsiyet metalaşmakta ve kadın bedeni üzerinden artı değer üretilmektedir (Marcuse, 1974, s. 285). Dolayısıyla, kapitalizm ve toplumsal cinsiyet boyutuyla da sağlık haberlerinin rolünün tartışılması önemlidir.
} 
"Hayır, kesinlikle yok" diyen yalnızca 4 sağık profesyoneli ve 2 medya profesyoneli çıkmıştır" (2010, s. 29).

Dijitalleşme ile medyadaki yapısal sorunların ciddi bir değişiklik geçirdiğini söylemek oldukça güçtür. Sadece Türkiye'de değil, dünyada da medya profesyonelleri "medyayı kurtarmak" adına çeşitli çözüm önerileri ortaya koymaya çalışmıştır. Mevcut ekonomik modellerin sürdürülebilirliğine ilişkin yapılan tartışmalar yeni gelir modellerinin önünü açmış ancak, yeni iş modelleri de kamu yararından çok, yeni reklam gelirlerini büyütmeye ve yeni trendlere adapte olmaya yönelik olmuştur (Kaye \& Quinn, 2010, s. 19). Ana akım medyadaki örgütlenme ve üretim tarzında yapısal değişiklikler yaşanmadığı için sektör içinde çalışan gazetecilerin "gazeteci profili" ideolojik olarak sabit kalmaktadır. ${ }^{4}$ Dijitalleşme ile doğal reklam (native advertising, advertorial) içerikleri yayıncılık alanını bir parçası haline gelmekte ve editörler -her ne kadar buna direnen ayrıksı örnekler olsa da- reklamcılığı kendi iş akışının bir parçası haline getirmektedir (Li, 2019, s. 535-536).

Sağlık haberlerindeki bir diğer önemli görülen sorun -akredite haber kaynaklarına bağlıık ve objektif habercilik ideali gibi- liberal çoğulcu yaklaşıma bağlı gazetecilik pratiğine yerleşmiş genelgeçer kodlardır. Ana akım gazetecilik habitusunda habercilik pratiğine ilişkin yerleşmiş kodlar, haberlerin belirli kaynaklar üzerinden kurulmasına ve bu da toplumdaki hâkim güç ve iktidar ilişkilerinin sorgulanmadan yeniden üretilmesine neden olmaktadır (Özer, 2010, s. 116). Dolayısıyla gazeteciler, sağlık konulu haberlerde kültürel kodlardan, mesleki normlardan, editöryal süreçlerden hareketle bir çerçeve sunmaktadır. Böylece toplumsal eşitsizlikler, sağlık konulu haberlerinde dahi yeniden üretilmektedir (Hodgetts, Chamberlain, Scammell, Karapu, \& Nikora, 2007, s. 61-62). Bu durum, toplumdaki sosyopolitik sorunların görünürlüğünü azalttığı gibi; sağlık haberlerinin -doğrudan ya da dolaylı olarakticari ve aynı zamanda politik yönelimlerle kurulabilmesine zemin hazırlamaktadır. Çünkü, politik alanı ekonomik alandan ayrı düşünmek, medya alanındaki siyasi kutuplaşmanın nasıl şekillendiğini yorumlamak adına eksik bir yaklaşım olacaktır. Siyaset alanının sağlık haberlerine etkisinin ve haberlerin

\footnotetext{
${ }^{4} \mathrm{Bu}$ noktada alternatif medya olarak tanımlanan mecralarda gerçekleştirilen gazetecilik pratiği hem örgütlenme dinamiğindeki hem de haber üretim sürecindeki farklılılar bakımından ayrıksı bir noktada bulunmaktadır. Bu bakımdan sektörel düzeyde ve mesleki ideal ve motivasyonları çerçevesinde ana akım medyanın ve alternatif medyanın farklı habitusları olduğu söylenebilir (Cangöz, 2015, s. 222-226).
} 
güç ve iktidar ilişkilerini nasıl yansıttığı konusunun, açıklanan bu unsurlar bağlamında değerlendirilmesi daha bütüncül bir bakış açısı sunacaktır.

\section{KUTUPLAŞMA VE "iKíLi KARŞITLIĞıN” KAVRAMSAL TEMELLERi}

Sosyoloji ve siyaset bilimi alanına atfedilen bir kavram olan kutuplaşma (polarization), kullanıldığı disipline bağlı olarak farklı anlam ve konumlara sahiptir. Siyaset bilimi bağlamında değerlendirildiğinde, kavramın politikadaki bölünmeleri "ölçmek" için kullanıldığı görülmektedir. Dolayısıyla, kutuplaşma kavramı siyaset bilimi üzerinden tartışıldığında, alanın konusu "siyasi kutuplaşma"dır (Talisse, 2019, s. 98). Siyaset bilimi bağlamında siyasi kutuplaşmayı üç farklı noktada değerlendirmek mümkündür. Bunlar siyasa (policy), ideolojik ve partizan kutuplaşmalardır (McCarty, 2019, s. 9).

Siyasa kutuplaşma, bazı kamu politikaları konusundaki aşırı görüşlerin zaman içinde daha yaygın hale geldiği bir süreçtir (Örneğin kürtaj konusundaki kamu politikaları üzerine karşıtıklar). İdeolojik kutuplaşma ise, siyasa kutuplaşma ile benzerlik taşımakla birlikte, seçmenlerin ideolojik pozisyonlarının merkezde ya da uçlarda yer almasını betimlemektedir. Örneğin kutuplaşma, merkez sağ ya da merkez sol şeklinde gerçekleşiyorsa bu durum "çok az ideolojik kutuplaşma" olduğunu göstermektedir. Son kutuplaşma türü olan partizan kutuplaşma ise seçmenlerin ve politikacıların konumlarının siyasi partiler arasında nasıl değiştiği ile ilişkili bir kavramdır. Taraflar arasındaki kutuplaşmanın organize edildiği durumlar için kullanılmaktadır (McCarty, 2019, s. 10-11). Partizan kutuplaşmalarda ideolojik yönelim çok yüksek düzeyde olduğu için "tek biçimlilik" ön plandadır ve "Iımlılar" bu kategori içinde yer almamaktadır (Talisse, 2019, s. 98). Bu bağlamda, siyaset biliminde "ölçüm" özelliği vurgulanan "kutuplaşma" kavramı -bu çalışmada da olduğu gibi- bir kuramsal yaklaşım olarak değerlendirmek istenildiğinde, kavramın sosyolojik temellerine de değinmek önemli görülmektedir.

Kutuplaşma, sosyolojik açıdan değerlendirildiğinde, çok sayıda farklı bağlamda gözlemlenen iki karşıt uçta yoğunlaşma eğilimi olarak tanımlanmaktadır. Ancak, "sosyolojik tipolojilerin pek çoğu, kutuplu türleri ya da uçları bulunan durum tanımlamalarıdır" (Marshall, 1999, s. 439). Kutuplaşmanın farklı bağlamlarda kullanılması, kavramın temellendirildiği paradigma ile ilişkilidir. Örneğin, "Karl Marx, kapitalist toplumlardaki sınıfları burjuvazi ve proletarya olarak 'iki büyük düşman kamp' şeklinde kutuplaştırmıştır" (Marshall, 1999, s. 440). Bir başka tanımlamada, kutuplaşmanın "ikili olma" durumuna gönderme yapılarak, "aynı toplumdaki zümrelerde meydana çıkan çatışkan eğilimlerin başııa karşıt iki 
kutupta toplanması hali" şeklinde ifade edilmektedir (Ülken, 1969, s. 184). Dolayısıyla, kutuplaşmayı ayrışmayı ortaya çıkaran bir unsur olarak değil, var olan iki kutuplu ayrışmalarda gerçekleşen yoğunlaşmalar olarak tanımlamak daha doğru olacaktır.

Zygmunt Bauman (2012, s. 9-11) ise, küreselleşme olgusunu da hesaba katarak günümüzdeki kutuplaşmanın çok boyutlu olduğuna işaret etmektedir. Bauman, zengin ve fakir, köylü ve şehirli, normal ve anormal gibi kutuplaşmalardan değil, daha çok iç içe geçmiş ve birbirini etkileyen bir kutuplaşmadan söz etmektedir. Küreselleşme, ulusal hükümetlerin karar alma sürecinde etkili olabilmekte ve bu durum, ortak kültürün birbirinden tamamen farklı iki yoruma hizmet eden ayırt edici özelliklerini çatallaştırmakta ve kutuplaştırmaktadır.

Farklı bağlamları olsa da kutuplaşmayı yaratan olguların temelinde "ikili karşıtlıklar"ın bulunduğu söylenebilir. Özellikle ulus-devletleri, "devlet" kimliğini sağlamlaştırmak için ikili karşıtıkları kullanmaktadır. Dolayısıyla, kutuplaşmayı besleyen "karşıtlık" aynı zamanda kültürel, toplumsal ve siyasal konsolidasyonu da sağlamaktadır. Yapısal antropolojinin önemli düşünürlerinden Claude LéviStrauss (1995, s. 23), dilbilim yöntemini kültüre uygulayarak toplumların yapısını açıklamada "ikili karşıtlık (binary opposition)" kavramını kullanmaktadır. ${ }^{5}$ Dilin yapısındaki zıtlıklardan hareketle, bilinç dışı ortaya çıkan şemalar sosyal, ekonomik ve kültürel yapıyı etkileyebilmektedir. Böylece kültürler, kendi gibi olmayan diğer kültürleri "biz ve öteki" gibi ikili karşıtlıklar üzerinden değerlendirmektedir. Bu durum, ortak kültürler içinde de görülmektedir: Tabakalar, sınıflar, mesleki ve dinsel çevreler gibi toplumu oluşturan bütün topluluklar "sonradan her birinin aşırı bir önem atfederek sarılacağı farklılıklar geliştirirler".

Bu konumlandırma hali, kutuplaşmayı etkileyebileceği gibi toplulukların kendi içindeki bağlarını da güçlendirmektedir. Kutuplaşmanın kavramsal temelinde "biz ve diğerleri"ni oluşturacak kategoriler bulunmaktadır. Bu kategoriler sistemin devamılı ı̆ı için "anlam"ı inşa etmektedir. İkili karşıt kategoriler, aynı zamanda birbirlerinin varlı̆̆ının da güvencesidir. Çünkü, bir kategorinin kendi içindeki mutlaklığıı karşıt olan kategorinin varlığını da meşru kılmaktadır. Bu açıdan, her şeyin ya A kategorisi ya da B kategorisi olduğu durumlar "mükemmel bir ikili karşıtlık" olarak tanımlanmaktadır (Fiske, 2003, s. 153). Levi-Straus (1994, s. 259), kültürel ve dilsel dizgelerdeki "sınıflandırıcı yönelim" sayesinde genelin özelle,

${ }^{5}$ Claude Lévi-Strauss'dan önce Ferdinand de Saussure'ün dilbilim özelinde geliştirdiği "ikili karşıtlık" olgusu, dilbilim alanındaki yapısalıı metodolojinin paradigmasını oluşturmaktadır (Saussure, 1985). 
soyutla da somutun birleştirilebileceğini belirtmektedir. Sınıflandırma ikili karşıtlıklara göre işlevsel kılınmakta ve ikili karşıtlıkların olmayışı sınıflandırmayı da sonlandırmaktadır. Dolayısıyla ikili karşıtlıklar, işlevsel kutuplaştırıcı şemaların oluşmasında bir temel oluşturmaktadır.

Bu noktada yapısalcı bir perspektiften bakıldığında, kutuplaşmanın da özünde "birbirini besleyen" iki karşıt kategorinin kendi kutuplarındaki yoğunlaşma eğilimi olduğu söylenebilir. Ancak, her kavram ve olguyu kültürel ya da toplumsal bağlamda "sadece birbirini tamamlayan zıtlıklar" üzerinden çözümlemek indirgemeci bir yaklaşım olacaktır. Örneğin, sınıf mücadelesi "uzlaşmaz bir karşıtlık"tır. Tipolojik bir çerçevede değerlendirildiğinde bu uzlaşmaz karşıtlıkların içinde barındırdığı zıtlıkların, birbirini tamamlayan karşıt kutuplar olduğu söylenebilir. Ancak, sınıf mücadelesi gibi tarihsel ve sosyolojik olguları, -Zizek'in (2011, s. 43) de ifade ettiği gibi- sadece kozmik zıtlıklar (akıl-duygular, aktif-pasif, bilinç-bilinçdışı, yin-yang) gibi karşıt ama ilişkili kavramlarla açıklamak, indirgemeci ve ideolojik bir karakter taşımaktadır. Bu noktada zıtlıkların ve kategorilerin ontolojisi üzerine sorgulamalara gidilmesi önemli görülmektedir. Dil ve kültür bağlamındaki karşıtlıkların da ötesindeki özne-nesne ilişkisi, özünde gerçek süreçler, toplumsal yaşamın üretimi ve yeniden üretimi dolayımıyla gerçekleşmektedir. Bu bakımdan, ister özne-nesne kutuplaşması olsun ister Kantçı bir bakış açısıyla numenal dünya-fenomenel dünya ikiliği kurulsun; "kategorilerin eksik ve üretilemeyecek bir şeyin kalıpları, bu şeyin tamamlayıcı ideolojisi olduğu" yaklaşımı (Adorno, 2016, s. 68-69), kutuplaşma ve kategori kavramlarının tek boyutlu değerlendirilmemesi gerektiğine işaret etmektedir. Bu bakımdan, kutuplaşma ve "karşıtlıklar" kavramlarını yapısalcı ontolojinin yanında, Marksist bir perspektiften de değerlendirmek önem taşımaktadır.

Georg W. F. Hegel'in zıtların sentezini savunan idealist diyalektik anlayışı (tez- antitez-sentez), Karl Marx tarafından üretim ilişkileri, toplumsal varlık ve bilinç sorgulaması üzerinden diyalektik materyalist bir çerçevede konumlandırılmıştır. Toplumsal varlığın bilinci belirlediğini savunan Marx (1979, s. 25), toplumlarda karşıtlıkları yaratan şeyin özünde üretim ilişkileri olduğunu ifade etmiş ve buradan hareketle burjuvazi ve proletarya ikili karşıtlığını kurmuştur. Ancak, burada kurulan kutuplu yapı (burjuvazi/proletarya) bir nedeni değil, bir sonucu temsil etmektedir. Dolayısıyla, maddi üretimin belirleyici olduğu bu durum, sınıfsal ikili karşıtlığı yaratmıştır. Zizek'e $(2011$, s. 42) göre ise, artık tek sınıf kapitalist sınıftır. Proletarya artık bir sınıf değildir ancak, "karşıtı ile karşılaşan, sınıf olmayan bir sınıftır." Dolayısıyla, sınıf pozisyonunu reddetmeye dönük tarihsel eğilim, karşıt bir sınıf pozisyonu yaratmaktadır. 
Bu bağlamda, Marksist çerçevede bu karşıt pozisyonu Wayne'in (2003, s. 222) de ifade ettiği gibi egemen (dominant) ve bağımlı (subordinate) kutuplar olarak kurmak daha doğru olacaktır.

Birbirleriyle etkileşim içinde olan egemen ve bağımlı kutupların (bunları sermaye ve emek, merkez ve çevre, beyaz ve siyah gibi ikili karşıtlarla genişletebiliriz), diyalektik olarak 4 kilit niteliği olduğu söylenebilir (Wayne, 2003, s. 222-224):

"1-Egemen ve bağımlı kutuplar arasındaki çatışma mecburidir. Çünkü, bağımlı kutuplar, bağımlı konumlarına karşı sürekli bir direniş içindeyken, egemen kutuplar egemenliğin yeniden üretimi için uğraşmaktadır.

2-Farklı kutuplar birbiriyle çatışma içinde olduğu kadar, aynı zamanda birbirine bă̆ımlıdırlar. Çünkü bir kutbun kimliğini belirleyen şey diğerinin konumudur. Bir kutuptan gelecek her eylem, diğer kutbun karşıt konumunu üretmektedir.

3-Hem egemen hem de bağımlı kutuplar kendi içlerinde -mecburi olarak-bölünmüşlerdir. Çünkü, çatışmaları ve karşııkı bağımlııkları her kutbun merkezine nüfuz etmektedir. Marksizm içinde ortaya çıkan ve toplumsal aktörlerin eylemlerindeki iç çelişkileri, konsept ve normları gün yüzüne çıkararak işleyen bu eleştirel stratejiye 'içkin eleştiri' adı verilmektedir. lçkin eleştiri, kavramların ve normların birbiriyle veya bağlı bulundukları toplumsal ilişkilerle nasıl çelişki içine girdiklerini incelemektedir. Örneğin, ABD hükümetinin barış adına savaşı meşrulaştırması ya da savunma adına ilk saldırıda nükleer silahları kullanması, kavram ve normların 'içkin çelişkilerini' göstermektedir.

4-Egemen kutup, var olan kutuplu yapının muhafaza edilmesini temsil etmektedir. Bağım/ı kutup ise, kutuplaştırmayı oluşturan genel yapının çelişkilerini yenebilecek ve yeni bir düzenin gelebileceği konumu veya bakış açısını temsil etmektedir. Bağımı kutbun bu bakış açısı, sermaye ile emek arasındaki prototip çatışması durumunda bile- egemen kutbun temsil ettiği veya başardığı her şeyin yok edilmesini gerektirmemektedir. Bunun yerine, kriz durumlarında bir çıkış yolunu, var olan kutuplaşmalar içinde potansiyellerin geliştirilmesini ve bu kutuplaşmanın en iyi unsurları arasında sentez oluşturacak yeni bir yapıyı işaret etmektedir. Böylece, sermaye sonrası toplum bile, sermayeden miras alınan üretici güçlerin, kültürel zenginliğin ve ilerici siyasi başarıların (mevcut haliyle sınırlı olsa bile demokrasi) üzerine inşa edilecektir."

Görüldüğü üzere, kutuplaşmalar egemen yapının sabit karakteri üzerinde (egemen kutupbağımlı kutup) radikal değişimler adına yönlendirici etkiye sahip değildir. Dolayısıyla, kutuplaşmanın bölünmeleri tetiklediği kadar aynı zamanda, sistemin devamlılığını sağlayan unsurlardan biri olduğu söylenebilir. Çünkü, "kutuplaşmış koşullarda yurttaşlar, partizan ön yargılara yönelmekte ve normal koşullarda 'güçlü' olduğunu düşündükleri argümanları görmezden gelebilmektedirler." Bu açıdan,

${ }^{6}$ Mike Wayne'e göre, değinilen son nitelik egemen bir medya değeri olan "denge" ölçütüne dönüşebilmektedir (2003, s. 224). 
yönlendirilmiş değerlendirmeler, yurttaşların temel bilgileri görmezden gelmesine neden olmaktadır (Druckman, Peterson, \& Slothuus, 2013, s. 75).

Bu noktada "yönlendirilmiş değerlendirmeler"i yaratan unsurların başında kitle iletişim araçlarının geldiği söylenebilir. Dilbilimsel, kültürel ve ekonomik bağlamda kutuplar arasındaki diyalektik ilişki, kuşkusuz, haber üretim sürecinin de bir parçasıdır. Ifade edildiği üzere, hem toplumların üretim ilişkileri ve bu ilişkilerdeki konumlanma süreci hem de yapısalıı bağlamda dil ve kültür gibi yapıların ikili karşıtlık ilişkisi; haber söyleminin nasıl inşa edildiği konusunda fikir verebilecek iki önemli noktadır. Kitle iletişiminin örgütlü yapısındaki kapitalist üretim ilişkilerinin sorgulanması ve bu üretim ilişkilerinden hareketle somut pratikte ideolojinin politik, kültürel ve toplumsal bağlamda nasıl üretildiğinin çözümlenmesi eleştirel ekonomi politik çalışmaların konusudur (Golding \& Murdock, 1991, s. 18). Ancak, bu çalışmanın problemi, medya metinleri ekseninde çerçevelenmiştir. Dolayısıyla, "haber" unsurunu merkeze çeken bu çalışmada, hem haber metinlerindeki temaların hem de haberde üretilen söylemlerin dikkate alınması araştırma sorularıyla daha tutarılı bir karakter taşıyacaktır.

Bu bağlamda, anlamın dildeki ikili karşıtıklar üzerinden üretildiğini savunan Saussure'ün (1985, s. 16) ve Levi-Strauss'un kültürü merkeze çeken "ikili karşıtlıklar" kavramsallaştırmasından hareketle, haberdeki söylemin de ikili karşıtlıklar üzerinden oluşturulduğu söylenebilir. Haber konusu olan eylem, durum ya da olgu yerli-yabancı, bizler-onlar, dostlar-düşmanlar, erkekler-kadınlar, merkezdekilerçevredekiler gibi karşıtıklar üzerinden inşa edilmektedir. Çünkü, bu şekilde kitle iletişim araçları aracılığıyla yapılandırılan "biz" ve "öteki" konumları meşrulaştııılmaktadır. Bu noktadan hareketle, haber ve kutuplaşma arasındaki ilişkinin irdelenmesi önemli görülmektedir.

\section{MEDYA, SIYYSET VE KUTUPLAŞMA íLişKISi}

Siyasetin medya üzerindeki etkilerine bakıldı̆ıında, siyasi angajmanlarla hareket eden ya da doğrudan bir siyasi parti veya ideolojik gruplar tarafından yaratılan medya organlarının konunun merkezinde olduğu görülmektedir. Partizan medya olarak tanımlanan bu medya oluşumları haber vermekten çok, okuru belirli bir görüşe yönlendirmeyi amaçlayan "gazetecilik" uygulamalarıdır (Uzun, 2014, s. 136). Dolayısıyla, kutuplaşmanın merkezinde bulunmaktadırlar. Partizan medyanın etkilerini merkeze çeken çalışmalara bakıldığında, çağdaş partizan medyanın kutuplaşmaya katkıda bulunduğunu ancak, tek tip veya doğrudan bir şekilde kutuplaşmanın gerçekleşmediği yönünde bulgular vardır (Nadler 
\& Bauer, 2019, s. 240). Bu bağlamda, kutuplaşmanın başlangıç noktası siyaset alanıyken, medyanın kutuplaşan grupların konsolidasyonunu sağlama görevini yerine getirdiği söylenebilir. Bu anlamda, konu Türkiye özelinde değerlendirildiğinde, müzakere ve ikna çabasının sınırlı olduğu siyaset yapma tarzı, ülkedeki kutuplaşmayı beslerken; medya da bu kutuplaşma içindeki en temel öznelerden biri konumundadır (Ağırdır, 2010, s. 2).

Medya ekseninde gerçekleşen kutuplaşmadaki temel faktörlerden bir diğerinin de izlerkitlenin medya seçimleri olduğu söylenebilir. Bu noktada partizan kitleler, kendi ideolojik yönelimlerine yakın buldukları medya organlarını takip etmekte (Mutz, 2006, s. 226) ve bu anlamda "tercihler" dolayımıyla bir kutuplaşma gerçekleşmektedir (Stroud, 2010, s. 558). Dolayısıyla, "seçici maruz kalma"nın bir sonucu olarak, partizan seçmenlerin sabit siyaset anlayışlarına sahip oldukları, olayları ideolojik ve partizan bir mercekle yorumladıkları söylenebilir. İdeolojik içerikler, seçmenleri daha "aşırı" konumları kabul etmeye itebilmektedir (McCarty, 2019, s. 88).

Bu anlamda, medya içeriklerinin hem ideolojik hem de motivasyon etkisi bulunmaktadır. İdeolojik etki olarak, medya ortamında yaşanacak bir değişiklik, içeriklere maruz kalan yurttaşların ideolojik görüşlerinde kutuplaşmaya (bir yerde toplanmaya) veya ayrışmaya (parçalanmaya) neden olabilmektedir. Sağ ve sol ayrımı bunun en basit örneğidir. Motivasyon etkisi ise, siyasi içeriğe maruz kalan bireylerin kutuplaşma derecesi ile ilişkilidir. Bu motivasyon düzeyi, bireylerin siyasetle olan ilişkisini ve dolayısıyla oy vermeye yönelik eğilimini etkileyebilmektedir (Campante \& Hojman, 2013, s. 80). Örneğin, "aşırı sağ" ve "aşırı sol" şeklinde ayrılan kutuplar, ideolojik yönelimin "ölçüsünü" işaret etmekte ve medya içeriklerinin motivasyon etkisini göstermektedir.

Medyanın ideolojik ve motivasyon etkilerinden hareketle yapılan başat çalışmaları temel aldığımızda medya içeriklerinin kutuplaşmayı ne ölçüde etkilediği konusunda genelleyici bir yargıda bulunmak güçtür. Yapılan son dönem araştırmaların büyük bir bölümü Amerika Birleşik Devletleri'ndeki (ABD) medya eksenli politik kutuplaşmaya yöneliktir. Bu anlamda, son dönemdeki ilgili çalışmalara kısaca değinmek yerinde olacaktır. Sedona Chinn vd.'nin (2020) 1985 ile 2017 yılları arasında ABD'de ana akım gazetelerde yer alan iklim değişikliğine ilişkin tüm haberleri, siyasallaşma ve kutuplaşma bağlamında inceledikleri çalışmalarında; haberlerde bilim insanlarına göre siyasi aktörlerin daha çok öne çıktığı, 
haberlerin giderek daha politik hale geldiği, siyasi söylemlerin belirgin şekilde farklı olması nedeniyle haberlerin giderek kutuplaştığı sonuçlarına ulaşmışlardır.

Aynı araştırma modeli temel alınarak, P. Sol Hart vd. (2020), ABD'de haber kanalları ve gazetelerde (basılı ve dijital) yayımlanan COVID-19'a ilişkin haberlerde, siyasallaşma ve kutuplaşma düzeyini incelemişlerdir. Çalışmada, hem gazetelerin hem de internetteki haberlerin olukça kutuplaşmış olduğu; gazetelerde politikacıların bilim insanlarından daha sık göründüğü ancak, internetteki haberlerde politikacıların ve bilim insanlarının daha eşit şekilde yer aldığı sonucuna ulaşmışlardır. Bu bağlamda politik ve kutuplu bir perspektifte verilen COVID-19 konulu haberlerin ABD'deki bireylerin COVID-19'a ilişkin tutumlarında da kutuplaşmaya neden olabileceği belirtilmiştir. Demokratlar ve Cumhuriyetçiler arasındaki COVID-19'a ilişkin görüş farklılıklarının medya metinlerine bu şekilde yansımasının sadece politik bağlamda değil, halk sağlığı açısından da değerlendirilmesi yerinde olacaktır. Çünkü, Hart vd.'nin (2020) çeşitli referanslar vererek değindiği diğer çalışmalarda Demokratların sosyal mesafe kurallarına uyma olasılı̆ıının daha yüksek olduğuna, Cumhuriyetçilerin ve Başkan Trump'a daha fazla inanan bireylerin ise bunu yapma olasılığının düşük olduğuna yönelik bulgular vardır (Hart, Chinn, \& Soroka, 2020, s. 3).

Çalışmadaki bir diğer önemli bulgu ise, mecra olarak farklılık gösteren (basılı ve dijital) alanlarda gerçekleşen kutuplaşma modellerindeki farklılıklardır. Buna göre, haber odası normlarındaki ön yargılar ve izleyicilerin dikkatini bir hikayeye çekme arzusu, içeriğin daha fazla siyasallaşmasına yol açabilmektedir (Hart, Chinn, \& Soroka, 2020, s. 4). Ancak, siyasallaşma derecesinin (siyasetçilerin konuyla bağlantılı olarak bahsedilme derecesi) basılı haberlerde daha yüksek olduğu görülse de kutuplaşmanın (siyasetçilerin konuyla bağlantılı olarak nasıl bahsedildiği) her iki mecrada da yüksek seviyede olduğu sonucuna ulaşıımıştır (s. 13). Dolayısıyla, ilgili çalışmalardan da anlaşılacağı üzere, haber metinleri çözümlemelerinde siyasallaşma "ne kadar?"; kutuplaşma ise "nasıl?" soruları çerçevesinde analiz edilmektedir. Bu bağlamda değinmek gerekir ki, COVID-19 haberlerinin kutuplaşma ve siyasallaşma bağlamında nasıl değerlendirileceği konusunda Chinn vd.'nin (2020) ve Hart vd.'nin (2020) çalışmaları, bu araştırmanın inşasında da -metodolojik farklııklar olmakla birlikte- önemli çıkış noktaları oluşturmuştur.

Medyadaki kutuplaşmanın kitlelerin partizan konumunu yoğunlaştırdığına değinen çalışmalardan farklı olarak, medyadaki kutuplaşmanın kitleleri sanıldığı kadar partizanlaştırmadığı 
yönünde veriler de bulunmaktadır. Markus Prior'un (2013) ABD medyasını ve kutuplaşmayı merkeze alan araştırmasında, çoğu ABD seçmeninin siyasi tutumlarının oldukça "ılımlı" olmasına rağmen, konulara siyasi olarak müdahil olanlar arasında "bir miktar" kutuplaşma gerçekleştiğini göstermiştir. Ancak, aynı çalışmada, partizan bir tutumla hareket eden medya organlarının "sıradan Amerikalıları" daha partizan yaptığına dair kesin bir kanıta rastlanmamıştır. Dolayısıyla, kutuplaşma ve partizanlık ilişkisi sadece medya metinleriyle değil, aynı zamanda partizan bireylerin kendilerini konumlandırdıkları parti ya da hareketlerin argümanlarının medya metinleriyle uyumuyla da ilgilidir.

James N. Druckman vd., kutuplaşmanın bireylerin politik görüşlerini etkileyip etkilemediğini sorguladıkları çalışmalarında; kutuplaşmış ortamların yurttaşların karar verme şeklini temelden değiştirdiğine dair çeşitli kanıtlar ortaya koymuşlardır. Çalışmadaki önemli bulgulardan birisi aynı güçte ancak, karşıt şekilde inşa edilen çerçeveler sunulduğunda; kişilerin yatkın olduğu partinin argümanlarıyla çerçeveler uyuşmadığında, bu çerçevelerin bireyleri etkilemede başarısız olduğudur. Bu bakımdan, mutlak kutuplaşmayı tek bir kritere göre değerlendirmek yanlış olacaktır. Metinlerde üretilen çerçeveler, kişilerin bağlı bulunduğu partilerin argümanlarıyla eşleşmiyorsa, medyada sunulan çerçeveler etkisiz kalacaktır. Aynı şekilde, medyada kutuplaştırıcı etkisi zayıf argümanlar sunulduğunda; bu argümanlar bireyin bağlı bulunduğu partiden bir onay aldıysa çerçeveler daha güçlü şekilde değerlendirilmektedir (2013, s. 73).

Sözü edilen vurgu noktalardan hareketle şu yargı çıkarılabilir: Haberlerde sunulan çerçevelerin doğrudan doğruya politik fikirleri şekillendirdiği ve kutuplaşmayı ortaya çıkardığı söylenemez. Çünkü, politik aktörlerin söylem ve eylemleri kutuplaşmayı harekete geçiren/oluşturan temel unsurlardır. Ancak, kutuplaşmadan hareketle medya çerçevelerinin nasıl sunulduğu, "daha fazla müdahale edilmiş" bir akıl yürütmeyi beslemektedir. Dolayısıyla, medya metinleri partizan yaratamasa da "partizanlığın derecesini" ayarlayabilmektedir.

Medyanın yönlendirici etkisi eleştirel bir bakış açısıyla düşünüldüğünde, medya metinlerinin bir toplumdaki egemen ekonomik, sosyal ve siyasal üretim ilişkileri içinde yer aldığı (Inal, 1996, s. 29) ve bu anlamda güç ve iktidar ilişkilerinin taşıyıcısı olduğu belirtilmektedir (Vona Kurt, 2015, s. 194). Bu bağlamdan hareketle, toplumdaki güç ve iktidar ilişkilerinin bir yansıması olarak haber konularının ikili karşıtıklar üzerinden çerçevelendiği ve bu şekilde kültürel yapının bir yansıması olan "biz" ve "öteki" 
konumlarının meşru kılındığı ifade edilebilir. Dolayısıyla, medyanın konuları çerçeveleme biçimi, siyasi ve toplumsal düzeyde yaşanan kutuplaşmaların "itici gücü olma potansiyeline sahiptir" (Vona Kurt, 2015, s. 201).

Bu potansiyel, medya metinlerinde kurulan anlatılar ve dil aracılığıla yapılandırılmaktadır. Dolayısıyla, haber metinlerindeki her anlatının, ilgili dönemselliğin egemen kodlarının bir sunumu olduğu söylenebilir. Bu açıdan, kitle iletişim araçlarıyla sunulan anlatılar aynı zamanda tarihsel, ekonomik ve sosyal olguların rasyonalize edilmiş bir formudur. Çünkü, "anlatı, toplumsal-kültürel olayların ve nesnelerin betimlenmesine yarayan betimleyici konuşmanın özelleştirilmiş bir biçimidir" (Habermas, 2001, s. 569). Bu bakımdan iletişimde sunulan argümanların çerçevesi toplumsal yaşama belirli oranda hareket verebilmektedir.

Illetişim bilimleri alanında medyada kutuplaşmanın hangi unsurlar bağlamında analiz edileceği ucu açık bir konudur. Dolayısıyla, siyasi kutuplaşmayı sorgulayan çalışmalarda, araştırmacıların ele aldığı kuramsal yaklaşımın metodolojik modellerinden hareketle bir yöntem sunulmuş ve bu yönde çözümlemeler gerçekleştirilmişstir. Örneğin ilgili bölümde değinilen Chinn vd.'nin (2020, s. 118-121) ve Hart vd.'nin $(2020$, s. 2) çalışmalarında medya içeriklerindeki siyasallaşma, "bir konu ile bağlantılı olarak politikacılardan bahsedilme derecesine" bakılarak analiz edilmiştir. Aynı çalışmalarda kutuplaşma ise "bir konunun farklı siyasi partilerden aktörlerin varlığına göre nasıl değiştiği" şeklinde değerlendirilmiştir. Bir başka ifadeyle, siyasallaşma, siyasetçilerin haberlerde "ne sıklıkla" bahsedildiği ile ilgiliyken; kutuplaşma, farklı partilerin siyasetçilerinin konu hakkında nasıl sunuldukları konusundaki farklılıkları işaret etmektedir.

Dolayısıyla, kutuplaşmayı kavramsallaştırma noktasında, çalışmaların arkasına aldığı farklı paradigmalar gereği epistemolojik ve metodolojik farklılıklar olacaktır. Bu anlamda Chinn vd.'nin ve Hart vd.'nin çalışmaları -pozitivist bağlamda- siyasallaşma ve kutuplaşma analizlerine özgün bir metodoloji geliştirmesi bakımından önemlidir. Ancak, konu eleştirel bir perspektiften de değerlendirilmek istendiğinde nitel bir çözümlemeye de ihtiyaç duyulmaktadır. Bu bağlamda, bu çalışmada, özcü bir bakış açısından kaçınmak adına, değinilen ampirik çalışmaların referanslarından ve "medya metinlerinin kurduğu anlatı formlarıyla güç ve iktidar ilişkilerinin taşıyıcısı olduğu" argümanından hareketle ikili bir çözümleme gerçekleştirilmiştir. 


\section{ÇALIŞMANIN YÖNTEMI VE BULGULARI}

Bu araştırmada, amaçlı örnekleme tekniği ile belirlenmiş çalışma kümesiyle çalışılmıştır. Bu bağlamda, COVID-19 pandemisinin Türkiye'de normalleşme sonrası tekrar yükselişe geçtiği dönem olan 1 Ağustos 2020 tarihi ile pandeminin ikinci zirve noktasına ulaştığı 30 Eylül 2020 tarihleri arasında Türkiye'deki ana akım ve alternatif medyayı temsilen 2 gazetenin COVID-19 pandemisi ile ilgili yayımlanan ilk sayfa haberleri araştırma kapsamına dahil edilmiştir. Çalışmada çözümleme dönemi olarak Ağustos ve Eylül aylarının seçilmesinin sebebi, Türkiye'deki Haziran ve Temmuz aylarında gerileme gösteren COVID-19 pandemisinden kaynaklı vaka ve ölüm sayılarında Ağustos ve Eylül aylarında tekrar artış yaşanması ve Sağlık Bakanı Fahrettin Koca'nın "birinci dalganın ikinci pikinin" bu aylarda yaşandığını açıklamasıdır (Sözcü, 2020).

Gazetelerin ilk sayfalarının çözümlemeye alınmasının çeşitli nedenleri vardır: Bir gazetenin en önemli sayfası, "vitrin sayfası" olan birinci sayfadır. Burada ön plana çıkarılan haberler verilmektedir. Bu açıdan çalışma, incelenen gazetelerin ilk sayfalarındaki haberlerle sınırlandırılmıştır. Bu sınırlamaya gidilmesinin diğer önemli nedeni ise yapılacak nicel içerik analizine ek olarak, ilgili haberlere nitel bir analiz uygulanmak istenmesidir. Bu açıdan haberlerin daha derinlemesine incelenmesi adına bu yönde bir kısıtlamaya gidilmiştir.

Hart vd. (2020) ABD'de COVID-19'a ilişkin haberlerin kutuplaşmaya etkilerini araştırdıkları çalışmalarında, basılı formattaki gazetelerin içeriklerinde, ağ temelli yayınlardan daha fazla siyasal kutuplaşma görüldüğü sonucuna ulaşmışlardır (s. 13). Bu noktadan hareketle, Türkiye basınındaki kutuplaşmayı daha net görebilmek adına gazete formatındaki yayınlar seçilmiştir. ${ }^{7}$ Kutuplaşmayı belirli oranda siyasi partilere angaje olmuş yayın organlarında incelemek, malum bir konunun ilanı olacaktır. Ancak, görece "merkez" kabul edilen yayın organlarında kutuplaşmanın aranması, incelemeye değer bir konudur. Dolayısıyla, bu çalışmada örneklem olarak ilgili yayınların seçilmesinin sebebi, Hürriyet

${ }^{7}$ Gazete Pencere, PDF formatında dağıtımı olan bir yayın olmasına karşın, mizanpaj ve içerik özellikleri bakımından ba sılı gazete formatındadır. Dolayısıyla, format bağlamında Hürriyet gazetesi ile tutarıdır. 
gazetesinin ana akım medyada; Gazete Pencere'nin ${ }^{8}$ de alternatif medya alanında, ideolojik yönelim bağlamında görece "merkez" medya konumunda bulunmasıdır. ${ }^{9}$

Çalışmanın araştırma soruları ve kuramsal temelde değindiği noktalardan hareketle hem görgül hem de yorumsamacı bir araştırma yürütülmesi uygun görülmüştür. Haberler nicel içerik analizi tekniği ile incelenmiş, bu analizin bulgularından hareketle belirli haberler nitel içerik analiz tekniği ile çözümlenmiş̧tir. içerik analizi objektif, sistematik ve niceliksel veriler elde etmeyi amaçlayan bir araştırma tekniğidir (Berelson, 1952, s. 18). İçerik analizi genellikle kelimelerin içindeki fikirlere, argümanlara, iddialara ve temalara odaklanmaktadır (Benoit, 2010, s. 270). Buradan hareketle bu çalışmada, verilerin kodlanması ve değerlendirilmesi noktasında araştırmacı, alanyazındaki benzer çalışmaları incelemiş ve yapılan çalışmalarda kullanılan formlardan hareketle, bu çalışmaya özgü bir kodlama kılavuzu geliştirmiştir. Örneklem içindeki haberlerin tümü baştan sona okunarak kılavuzdaki kategoriler oluşturulmuş ve son aşamada nicel içerik analizinin yapılacağı beş farklı kategori belirlenmiştir. İki gazetenin Ağustos ve Eylül ayları içinde çıkan bütün sayıları incelenmiş ve toplamda 235 adet koronavirüse ilişkin haber tespit edilmiştir. IIlk bölümde gazetenin COVID-19 haberlerine ilişkin tonuna (Destekleyici, nötr, eleştirel) bakılmıştır. İkinci olarak haberde işlenen temalar belirlenmiştir. ${ }^{10}$ Üçüncü aşamada haberin önemlilik derecesine (Manşetten mi yoksa alt başıklardan mı verildiği) bakılmıştır. Incelenen son iki kategori ise "bilgi ve haber kaynakları" ve "haber kaynaklarının sunumu"dur. íki gazetedeki COVID-19'a ilişkin tüm haberler incelenip veriler forma kaydedildikten sonra, nicel araştırma yazııımı olan SPSS kullanılarak analiz edilmiştir. Veriler, araştırmanın kodlama güvenilirliğini sağlamak amacıyla, Anadolu Üniversitesi Basın ve Yayın Bölümü'nde öğretim elemanı olan bir araştırmacı tarafından tekrar kodlanmıştır. Araştırmacı 235 haber arasından rasgele seçilen 32 (\%14) haberi ikinci kez kodlamış ve karşılaştırma yapılmıştır. Kodlayııılar arasındaki görüş birliği, Huberman ve Miles (1994)

\footnotetext{
${ }^{8} 21$ Ekim 2019'da yayın hayatına başlayan ve Türkiye'nin ilk PDF gazetesi olan Gazete Pencere'nin Genel Yayın Yönetmenliğini yapan Yavuz Oğhan, herhangi bir siyasi yönelimi merkeze almayan ve okurlara "bütünü" göstermeyi amaçlayan bir gazete çıkarmayı hedeflediklerini belirtmektedir. Oğhan, kutuplaşmış Türkiye ortamında "herkesin birbiriyle konuşabilmesine" olanak sağlayacak ve yankı odalarının dışına çıkılmasına katkı sunacak bir ortam yaratmak istediklerini ifade etmektedir. Bu anlamda gazetenin hedef kitlesinin "makulü arayanlar" olduğunun altını çizmiştir. Gazetenin temel gelir modeli okuyucu aboneliğidir. Herhangi bir şirkete veya medya holdingine bağlılığı yoktur (NewsLabTurkey, 2020).

${ }^{9}$ Çalışma basındaki haber metinleri ile sınırlandırılmıştır. Bu bakımdan çalışmanın problemiyle tutarlı olarak örneklem seçiminde, gazetelerin tirajları ya da kitleleri etki gücü gibi unsurlar dikkate alınmamıştır.

${ }^{10}$ Eğer bir haber başlığı altında farklı temalar varsa, ağılıkta olan tema kodlanmıştır. Bir haber başlığı altında farklı temalara eşit şekilde ve eşit uzunlukta yer verildiyse ayrı birer haber olarak kodlanmıştır.
} 
tarafından önerilen "görüş birliği / (görüş birliği + görüş ayrıllğı)" x 100 formülü kullanılarak \%90,62 olarak hesaplanmıştır.

Son olarak, nicel analizde ortaya konulan temalar ve sunum biçimlerinden hareketle, araştırmacının örneklem için hangi birimlerin seçileceğine kendisinin karar verdiği olasılık dışı (amaçı) örneklem türüne başvurularak (Koçak \& Arun, 2006, s. 25) iki gazeteden seçilen toplam 12 haber nitel içerik analizi tekniği ile incelenmiştir. Nitel içerik analizi, metnin hem biçimsel yönlerini hem de örtük anlam içeriğini çalışma nesnesi olarak kabul etmektedir. Dolayısıyla, nitel içerik analizi, içeriklerin gizli anlamlarını ve ideolojik konumlarını çözümlemeyi hedeflemektedir (Mayring, 2004, s. 266-267). Türkiye'de kimi nitel içerik analizi yöntemiyle yapılan ve haber sunumlarının nasıl gerçekleştiğine odaklanan çalışmalar, doğrudan belirli bir model ya da form çerçevesinde tasarlanmamıştır. Çalışmaların metinlerdeki anlamsal yapılara odaklandığı görülmektedir (Aksoy \& Nisan, 2001; Yaylagül \& Çiçek, 2012; Güdekli, 2016). Bu bağlamda, bu çalışmanın son bölümünde Hürriyet gazetesi ile Gazete Pencere'nin Türkiye'deki pandemi sürecine ilişkin tutumunu yansıtan haberler seçilerek çözümlenmiştir.

\section{COVID-19 Haberlerinin Gazetelerdeki Sunumu}

Çalışma kapsamında, Ağustos ve Eylül ayları arasında Gazete Pencere ve Hürriyet'in COVID-19'a ilişkin haberlerine nicel içerik analizi uygulanmıştır. Haberin tonu, teması, haberin önemlilik derecesi, haber kaynağı ve haber kaynağının sunumu olmak üzere toplam beş ana kategori belirlenmiş, iki gazeteden toplam 235 haber incelenerek kodlaması yapılmıştır.

Tablo 1 COVID-19 Haberlerinde Siyasi Aktörlerin ve Bilim İnsanlarının Temsil Oranları

\begin{tabular}{lcc}
\hline & GAZETE PENCERE & HÜRRIYET \\
\hline Toplam COVID-19 Haberi Sayısı & 162 & 73 \\
Siyasi Aktörlerin Temsil Oranı & $\% 42(n=68)$ & $\% 38,4(n=28)$ \\
Bilim Insanlarının Temsil Oranı & $\% 24,7(n=40)$ & $\% 12,4(n=9)$ \\
\hline
\end{tabular}

İçerik analizinden hareketle Gazete Pencere'nin bulgularına bakıldı̆ı̆nda ilgili dönem aralığında toplamda 162 adet koronavirüs pandemisine ilişkin haber yayımlandığı görülmektedir. Hürriyet gazetesinde ise ilgili süre zarfında 73 adet haber yayımlanmıştır. Bu sayı, Gazete Pencere'de yayımlanan haberlerin yarısından da azdır. Bu çalışmanın araştırma sorularından biri "ilgili gazetelerde bilim insanlarının temsil oranlarıyla, siyasi liderlerin temsil oranlarının karşılaştırılmasıdır." Bu anlamda Hürriyet gazetesinde COVID-19'a ilişkin yapılan 73 haberin \%38,4'ünde $(n=28)$ valilik ve bakanlıklar gibi 
resmi kurumlar ve büyük bir bölümü iktidar kanadından olan siyasi kişiler yer almaktadır. Haberlerde bilim insanlarının temsil oranı ise \%12,4'tür ( $n=9)$. Gazete Pencere'deki COVID-19'a ilişkin 162 haberin temsil oranları incelendiğinde resmi kurumlar dahil siyasilerin temsil oranı \%42 ( $n=68)$, bilim insanlarının temsil oranı $\% 24,7(n=40)$ olarak saptanmıştır (Tablo 1).

Bu bağlamda, çalışmada uygulanan nicel içerik analizinden hareketle, alternatif ve ana akım medyada yayımlanan COVID-19 haberlerinde siyasetçiler, bilim insanlarından daha fazla temsil edilmiştir. İki gazete arasındaki temsil oranlarında ciddi bir farklıık gözlenmemiştir. Ayrıca, söz konusu veriler Chinn vd.'nin (2020, s. 118-121) ve Hart vd.'nin (2020, s. 2) sunduğu siyasallaşma ve kutuplaşma kategorileri bağlamında değerlendirildiğinde, iki gazetede de belirli oranda siyasallaşma ve kutuplaşma gerçekleştiği söylenebilir. Ancak, konuya ilişkin daha kapsamlı bir yorumda bulunmak adına gazetelerin verilerindeki farklılıkları incelemek yerinde olacaktır.

Tablo 2 COVID-19 Haberlerinin Tonu

\begin{tabular}{lcc}
\hline & GAZETE PENCERE & HÜRRIYET \\
\hline Toplam COVID-19 Haberi Sayısı & 162 & 73 \\
Destekleyici & $\% 0,6(n=1)$ & $\% 8,2(n=6)$ \\
Nötr & $\% 60,5(n=98)$ & $\% 74(n=54)$ \\
Eleştirel & $\% 38,9(n=63)$ & $\% 17,8(n=13)$ \\
\hline
\end{tabular}

İlgili gazetelerin haber sunumlarına bakıldığında, Gazete Pencere'de haberlerin \%60,5'i ( $n=98$ ) nötr bir tonda verilmiş; haberlerin \%38,9'u ( $n=63)$ ise eleştirel bir perspektiften sunulmuştur. Gazetenin destekleyici bir tonda yaklaştığı haber konusu neredeyse hiç yoktur $(n=1)$. Hürriyet gazetesinin haber sunum tonuna bakıldığında \%74 ( $n=54)$ nötr; \%17,8 ( $n=13$ ) eleştirel; \%8,2 ( $n=6)$ destekleyici tondadır (Tablo 2). Ancak, iki gazetenin eleştirel tonda sunduğu haber temaları farklılık göstermektedir.

Gazete Pencere'de genel anlamda sunulan 162 haber içinde farklı temalarda dengeli bir dağıım olduğu görülmektedir. Haberlerde en çok yer verilen konu/tema \%14,8 ( $n=24)$ ile "Vaka ve ölüm sayılarının doğru verilmemesi/şeffaflık" konusudur (Tablo 3). Bu konuya ilişkin içerikler, aynı zamanda gazetenin en çok eleştirel tonda verdiği ( $n=17)$ ve en çok manşetten sunduğu haberlerdir ( $n=7)$. Söz konusu bulgulardan hareketle Gazete Pencere'nin koronavirüs pandemisine ilişkin genel tutumunun, Türkiye'deki muhalefet kanadının kamuoyundaki genel söylemiyle paralellik taşıdığı söylenebilir. Ayrıca bu konu özelindeki haberlerde en çok "sağlık çalışanları/doktorlar/akademisyenler" $(n=10)$, siyasetçiler (Muhalefet) ( $n=4)$ ve Türk Tabipleri Birliği (TTB) ( $n=4)$ kaynak olarak gösterilmiştir. Buna ek olarak, 
gazetenin "sağlık çalışanları/doktorlar/akademisyenler" kaynak olarak kullandığı neredeyse bütün haberlerinde söz konusu kaynaklar nötr bir tonda $(n=19)$ sunulmuştur. Gazete, "vaka/ölüm sayılarındaki artış" temasını içeren toplam 17 haberin 13'ünde haber kaynağı olarak Sağlık Bakanı Fahrettin Koca'yı kullanmıştır. Buna ek olarak, Gazete Pencere'nin COVID-19'a ilişkin yurt dışındaki gelişmelere genişçe yer ayırması dikkat çekmektedir. Öyle ki, koronavirüse ilişkin haberlerinin \%13,6'sı ( $n=22$ ) yurt dışındaki gelişmelere ayrılmıştır.

Tablo 3 COVID-19 Haberlerinde En Çok Iş̧lenen Üç Konu

\begin{tabular}{|c|c|}
\hline \multicolumn{2}{|c|}{ GAZETE PENCERE } \\
\hline Toplam COVID-19 Haberi Sayısı & 162 \\
\hline Vaka ve ölüm sayılarının doğru verilmemesi/şeffaflık & $\% 14,8(n=24)$ \\
\hline Yurt dışındaki gelişmeler (Genel) & $\% 13,6(n=22)$ \\
\hline Vaka/ölüm sayıları artış & $\% 10,5(n=17)$ \\
\hline \multicolumn{2}{|l|}{ HÜRRIYET } \\
\hline Toplam COVID-19 Haberi Sayısı & 73 \\
\hline Önlemlere uyulmaması / karantinayı ihlal edenler & $\% 24,7(n=18)$ \\
\hline Tedaviye ilişkin süreçler (aşı, evde tedavi...gibi) & $\% 16,4(n=12)$ \\
\hline Yeni önlemler/Kısıtlamalar/Yasaklar & $\% 15,1(n=11)$ \\
\hline
\end{tabular}

Kategoriler çapraz tablolarla incelendiğinde Gazete Pencere'nin en çok eleştirel tonda verdiği diğer haberler arasında "Devlet yetkililerinin kısıtlamalara uymaması/kısıtlamalarda çifte standartlar" ( $n=10)$ ve "Salgınla mücadelede hükümetin yetersiz kalması/ç̧elişkiler" (n=12) başııkı konular bulunmaktadır. Dolayısıyla, bu noktada da muhalefet tarafının konuya ilişkin kendisini konumlandırdığı söylem, farklı kaynaklardan hareketle "eleştirel bir tonda" gündeme getirilmiştir. Ancak, gazetenin bazı haberlerinde haber kaynă̆ı olarak iktidar kanadından haber kaynaklarına geniş bir şekilde yer vermesi dikkat çekmektedir. İktidar tarafından sırasıyla "resmi yetkililer" \%15,4 ( $n=25)$, "Fahrettin Koca /Sağlık Bakanlığı" \%13,6 (n=22), "Cumhurbaşkanlığı/Recep Tayyip Erdoğan” \%3,1 (n=5), “Milli Eğitim Bakanı Ziya Selçuk/Milli Eğitim Bakanlı̆̆ı \%2,5 (n=4), "Iç̧işleri Bakanı Süleyman Soylu/içiş̧leri Bakanlığı" \%1,9 (n=3), "Siyasetçiler (Cumhur İttifakı)" \% 1,2 (n=2) oranlarıyla haber kaynağı olarak yer almıştır. Sözü edilen haber kaynaklarının genelinin nötr bir tonda sunulmasına karşın, haber kaynaklarının "destekleyici" tonda sunulduğu haberlerde görece muhalif bir konumda bulunan "Türk Tabipleri Birliği" $(\% 5,6 ; n=9)$ ve "Siyasetçiler (Muhalefet)" (\%4,3; n=7) ön plana çıkmaktadır. Bu durum, kutuplu yapı içinde gazetenin kendisini "görece" bir yerde konumlandırdığı şeklinde okunabilmektedir. 
Hürriyet gazetesinde en çok yer alan konular sırasıyla "Önlemlere uyulmaması (eleştiri/tepki)" $(\% 24,7 ; \quad n=18) ;$ "Tedaviye ilişkin süreçler (aşı, evde tedavi vb.)" (\%16,4; $n=12)$ ve "Yeni önlemler/Kısıtlamalar/Yasaklar" (\%15,1;n=11) şeklindedir. Hürriyet gazetesinde tedaviye ilişkin süreçleri konu alan haberlerde en çok Sağlık Bakanı Fahrettin Koca $(n=4)$ haber kaynağı olarak gösterilirken, "Yeni önlemler/Kısıtlamalar/Yasaklar" kategorisindeki haberlerde en çok kaynak olarak gösterilenler Cumhurbaşkanı Recep Tayyip Erdoğan $(n=4)$ ve iç̧işleri Bakanı Süleyman Soylu $(n=3)$ 'dur. Ancak, yayımlanan haberlerin tümüne bakıldığında, haber kaynağı olarak en çok, \%39,7 ( $n=29)$ oranıyla, "gazetenin kendi muhabiri/yazarı/editörü"nün kullanıldığı görülmektedir. "Önlemlere uyulmaması (eleştiri/tepki)" teması en çok eleştirel yaklaşılan haber temasıdır ( $n=10)$. Aynı zamanda bu konu gazetenin en çok manşetten $(n=5)$ ve orta/alt başlıklardan $(n=7)$ verdiği haberlerdir. İlgili temada da gazetenin kendi muhabiri/editörü/yazarı haber kaynağı ( $n=14)$ konumundadır. Dolayısıyla, bu durum gazetenin sürece ilişkin kendi tutumu olarak da okunabilir. Buradaki ayrıksı nokta, gazetenin ilgili konudaki eleştirel tutumunun yetkili kurumlara değil, kurumların belirttiği önlemlere uymayan yurttaşlara yönelik olmasıdır. Aynı zamanda, Türk Tabipleri Birliği ve muhalefet konumundaki hiçbir siyasetçi Hürriyet gazetesinin COVID-19'a ilişkin haberlerinde kaynak olarak yer almamıştır. Dolayısıyla, bu yönde bir sunum iktidar tarafının genel söylemiyle uyumluluk taşımaktadır.

Buradan şu sonuçları çıkarmak yerinde olacaktır: İki gazete de farklı mecralarda yer almalarına karşın, ideolojik yönelim olarak merkez medya konumlarından ötürü partizan bir doğrultuda hareket etmemektedirler. Ancak, gazetelerin konuya ilişkin çerçevelediği tema ve kaynaklar farklıık göstermektedir. Hürriyet gazetesinin Gazete Pencere'ye göre, daha az haber, daha az çeşitli tema ve daha az çeşitli haber kaynağı ile konuya yaklaştığı söylenebilir. Ayrıca koronavirüs haberlerindeki aktörlerin farklı bağlamlarda sunulduğu görülmektedir. Söz konusu bulgular politik kutuplaşma adına bir bilgi verebilir ancak, tabloyu daha net yorumlayabilmek ve gazetelerin ideolojik tutumlarını görebilmek adına, haber içeriklerindeki söylemleri görünür kılacak nitel bir analiz ile konuyu incelemek önem taşımaktadır.

\section{COVID-19 Haberlerinde Üretilen Söylem}

Çalışmanın birinci aşamasında gerçekleştirilen nicel içerik analizinde, gazetelerin koronavirüs pandemisine ilişkin süreci farklı açılardan çerçevelediği görülmüş̧ür. Elde edilen bulgulara göre Gazete 
Pencere, konuya vaka ve ölüm sayılarının doğru verilmemesi, salgınla mücadelede hükümetin yetersiz kalması ve devlet yetkililerinin kısıtlamalara uymaması gibi temalar üzerinden yaklaşırken; Hürriyet gazetesi ise, yurttaşların önlemlere uymaması ve yeni önlemlere ilişkin bilgilendirme ekseninde haberlerini sunmuştur. Bu farklıık, gazetelerin haber kaynağı seçimi ve haber kaynağını sunuş biçiminde de görülmektedir. Ancak, bu çalışmanın araştırma sorularından olan gazetelerin "politik kutuplaşmayı nasıl yansıttığı" ve "politik kutuplaşmanın yeniden üretimine nasıl bir katkı sunduğu" sorularını nitel bir çözümlemeyle cevaplamak daha anlamlı görülmektedir. Bu bağlamda çalışmanın ikinci bölümünde, içerik analizinde ön plana çıkan konulardan hareketle ilgili gazetelerden toplam 12 haber seçilerek incelenmiştir.

Gazete Pencere'nin haberlerindeki söylemler incelendiğinde, salgınla mücadelede devlet yetkililerini merkeze çeken bir sunum yapıldığı görülmektedir. 15 Ağustos 2020 tarihli haberde görece muhalif bir konumda bulunan Türk Tabipleri Birliği'nin "SALGIN KONTROL ALTINA ALINAMIYOR" yorumu başlığa çekilerek verilmiştir. Haberde iktidar tarafının (ve aynı zamanda Hürriyet gazetesinin) sunduğu argümanların aksine, "ortaya çıkan olumsuz tablodan vatandaşın sorumlu tutulmasının kabul edilemez olduğu" ifadesi yer almaktadır. Haberde varolan durumdaki gerçek sorumlunun hükümetin olduğu TTB referans verilerek sunulmuştur. Dolayısıyla Gazete Pencere, Hürriyet gazetesinin söyleminin tam karşıtı bir söylemde kendisini konumlandırmakta ve politik alandaki kutuplaşmayı haber söylemi içinden tekrar kurmaktadır. Devlet yetkililerinin salgınla mücadelede yetersiz kaldığını işaret eden bir diğer haber de 18 Ağustos 2020 tarihli "DÜNYA ÖNLEM ALIYOR TÜRKIYE SADECE UYARIYOR" başlıklı haberdir. Haber içeriğinde yurt dışındaki önlemler referans alınarak Türkiye'de salgınla mücadelede devlet yetkililerinin eksikliği ön plana çıkarılmaktadır.

Bir önceki bölümdeki nicel içerik analizinin verilerine göre, Gazete Pencere'nin COVID-19'a ilişkin haberlerinde eleştirel olarak sunduğu içeriklerinin bir diğeri de "devlet yetkililerinin kısıtlamalara uymaması" konusudur. Bu konu aynı zamanda, siyaset alanında devlet yetkililerinin muhalefet kanadı tarafından en çok eleştirildiği konulardan birisidir. 24 Ağustos 2020 tarihli "O GÜN RISK YOK MUYDU" başlıklı haberde, iççşleri Bakanlığı'nın Ayasofya'nın açוışı sırasındaki kalabalığı görmezden gelip, 30 Ağustos Zafer Bayramı kutlamalarına kısıtlamalar getirdiği belirtilerek bu durum eleştirilmektedir. Haberde geçen "Açıklamaya tepki büyük. Özellikle Ayasofya'nın açılışı sırasında oluşan kalabalıkların görmezden gelinip yasak ve kısıtlamaların milli bayramlarda akıllara gelmesine" cümlesi ile cami 
statüsüne dönüştürülen Ayasofya'dan hareketle haber söyleminde Türkiye'deki muhafazakâr/dindar değerler ve ulusalcı/seküler değerler arasındaki ikili karşıtlık tekrar kurulmaktadır. Çünkü haberde, kalabalık ortamda yapılan bir açוlış eleştirilirken, ulusal bir bayramın kutlanamıyor olması ön plana çıkarılmıştır. Haberde Ayasofya'nın önündeki kalabalığı gösteren bir fotoğraf kullanılmıştır. Fotoğrafın haber söylemini desteklemek adına retorik işlevi gördüğü söylenebilir.

Aynı konu 26 Ağustos 2020 tarihli "30 AĞUSTOS RiSKLi AHLAT'TA RiSK YOK" başlıklı haberde ön plana çıkarılmaktadır. Ahlat Gençlik Kampı'nın açılışının Cumhur İttifakı üyelerince yoğun bir kalabalık önünde yapılmasına dikkat çekilerek bu durum eleştirilmektedir. Koronavirüs pandemisine ilişkin kısıtlamalardaki "çifte standart" durumu Gazete Pencere'nin haberlerinde işlenmeye devam edilmekte ve 1 Eylül 2020 tarihli "TEDBIR HAK GETIRE" başlıklı haber manşetten verilerek pandemi koşullarında Cumhurbaşkanı'nın Giresun'da miting yapması eleştirilmektedir. Haberde "30 Ağustos törenleri için uygulanan pandemi kuralları Erdoğan'ın ziyaretinde yok sayıldı" ifadesi yaşanılan çelişsili durumu işaret etmektedir. Bu temaya ilişkin incelenen haberlerin hepsinde, söylemlerin "30 Ağustos Zafer Bayramı kutlamalarının kısıtlanması" üzerinden kurulması, haber söylemlerindeki politik ve toplumsal kutuplaşmayı işaret etmesi adına önemlidir. Çünkü hem politik hem de toplumsal alanda kendisini gösteren "kurucu Türkiye Cumhuriyeti değerleri" ve "muhafazakâr yeni Türkiye değerleri" eksenli ikili karşıtık ilişkisi, gazetenin COVID-19 haberlerinin söyleminde de kendisini göstermektedir.

Gazete Pencere'nin haberlerinde merkeze aldığı bir diğer önemli konu, vaka ve ölüm sayılarının doğru olarak verilmediğine yöneliktir. 27 Ağustos 2020 tarihli manşet haberinde "BiLMEDiĞiMiz BiR ŞEY Mi VAR" başığı atılmış ve tabip odaları ve muhalefet kanadındaki milletvekillerinin bölgelerden yaptıkları açıklamalar ile resmi açıklamaların örtüşmediği vurgulanmıştır. 30 Ağustos 2020 tarihli "BELEDiYE BAŞKANLARI DAYANAMADI" başlığıyla manşetten veirlen haberde ise, Millet ittifakı'nın adayları olarak seçimi kazanan Ankara ve İstanbul belediye başkanlarının verilerin resmi açıklamalarla örtüşmediği yorumlarına yer verilmiştir. Dolayısıyla, Gazete Pencere'nin haberlerinde çerçevelediği konular ve argümanlar bağlamında, muhalefet kanadına yakın bir pozisyonda kendini konumlandırdığı haberde üretilen söylem düzeyinde de gözlenmektedir.

Hürriyet gazetesinin haberlerindeki söylemler incelendiğinde, haberlerin çok büyük bir bölümünde, yurttaşların ihmalkârlı̆ıını merkeze çeken bir sunum yapıldığı görülmektedir. 9 Ağustos 2020 
tarihli "IŞTE BU KAFA VIRÜSTEN BETER" başlıklı haberde, otobüs içinde maskesini doğru takmayan iki kişinin görevlilerle kavga etmesi anlatılmaktadır. "Işste bu kafa" söylemiyle virüsün yayılımı spesifik kişilere indirgenerek nedensellik kurulmuştur. Aynı nedenselliğin 19 Ağustos 2020 tarihli "HERKES AKLINI BAŞINA ALSIN-KORONALI ÇiĞ KÖFTECi" başlıklı haberde de kurulduğu görülmektedir. Haberde korona testi pozitif çıkan bir çiğ köftecinin çalışmaya devam etmesi eleştirilmektedir. Haberde "Devlet, sağlık ordusu, valilikler okulların açılacağı 21 Eylül öncesi vaka sayısını düşürmek için mücadele ederken, kural tanımaz vatandaşlar tehlike saçıyor" ifadeleri yer almaktadır. Haber söyleminden hareketle virüsün yayıımı özel kişilere indirgenmekte ve hükümet kanadına ilişkin sorgulamaların görünürlüğü azalmaktadır. Bu bağlamda şu noktayı ifade etmek yerinde olacaktır: COVID-19'un yayılımının kontrolden çıkması konusunda yurttaşların önlemlere yeterince uymamasının büyük etkisi bulunmaktadır. Ancak, konuyu sadece yurttaşların önlemlere uymamasına indirgemek ve bu çerçevede bir sunumu güçlendirmek, yetkili kurumların sürece ilişkin eksikliklerini ideolojik olarak gölgelemektedir. Bu anlamda Hürriyet gazetesinin, iktidar kanadının argümanlarıyla tutarlı bir söylem üretmesinin yanında, iktidarın mevcut eylemlerini meşru kılmaya dönük bir çerçeve sunduğu söylenebilir.

Gazetenin Ağustos ayındaki haberlerinde görünür olan ve konuyu yurttaşlara indirgeyen bu söylemin, gazetenin Eylül ayındaki koronavirüs pandemisine ilişkin bazı haberlerinde de üretildiği görülmektedir. 5 Eylül 2020 tarihli haberde "KARANTINALI SORUMSUZLAR" başlığı kullanılmıştır. Haber içeriğinde vaka artışlarının nedeni olarak karantina kurallarını ihlal eden yurttaşlar gösterilmektedir. 24 Eylül 2020 tarihli "PARA KESMEDi, HAPIS GELIYOR" başlığı ile manşetten verilen haberde, "Para cezasına rağmen salgın önlemlerine uymayarak korona vakalarında artışa yol açanlara hapis geliyor. Sorumsuzlara bir yıla kadar hapis cezası verilebilecek" ifadeleri yer almaktadır. Bu temaya ilişkin olarak incelenen haberlerin hepsinde "kural tanımaz vatandaşlar", "sorumsuzlar", "suçüstü yakalandılar" gibi söylem kalıplarının ön plana çıkarıldı̆ı görülmektedir. Bu şekilde, sadece "sorumsuzlar" söylemi üzerinden bir nedensel ilişki kurulmakta ve bu şekilde haber söyleminde ideolojik, indirgemeci ve kutuplaştırıcı bir retorik üretilmektedir.

Hürriyet gazetenin söylemlerinde saptanan bir diğer önemli unsur da gazetenin devlet yetkililerinin pandemiye ilişkin söylemlerini aktarış şeklidir. 1 Eylül 2020 tarihli "ŞEHIR ŞEHIR ANLATTI" başlığı ile manşetten verilen haberde, Hürriyet gazetesinin Genel Yayın Yönetmeni Ahmet Hakan'ın Sağlık Bakanı Fahrettin Koca ile yaptığı söyleşiye yer verilmiştir. Söyleşide, Türkiye'de salgının kontrol altına 
alındığı vurgusu yapııırken, Sağlık Bakanı Fahrettin Koca'nın “izmir'de kısmi artış var ama durum kontrol altında", "(...) Şanlıurfa ve Batman'da hastane sıkıntısı yaşandı ama sorun aşıldı" ve "Şu an önemli bir sorun yok" gibi güven verici ifadelerine yer verilmiştir. Bu anlamda haber söyleminde, hükümet kanadının salgın krizini başarılı bir şekilde yürüttüğü yönünde bir anlam üretilmektedir. Bu şekilde gazete, Gazete Pencere'de ve muhalif kutupta üretilen söylemin tam karşıtı bir pozisyonda kendisini konumlandırmakta ve politik alandaki kutuplaşmayı haber söylemi içinden tekrar kurmaktadır.

Genel anlamda bir değerlendirme yapmak gerekirse, haberler çerçevesinde yansıtılan karşıt kutuplu yapı, ilgili gazetelerde "devlet yetkililerinin yetersiziliği" ve "yurttaşların önlemlere uymaması" konuları ekseninde kurulmaktadır. Bu durum karşıt kutuplardaki partilerin argümanlarıyla da uyumluluk göstermektedir. Bu anlamda iki gazetenin de -dereceleri farklı olmakla birlikte- politik kutuplaşmayı koronavirüs pandemisine ilişkin metinlerinde yansıttığı ve yeniden ürettiği görülmektedir.

\section{SONUÇ VE DEĞERLENDIRME}

Bu çalışmada, Türkiye'yi etkisi altına alan koronavirüs pandemisinin alternatif ve ana akım basında nasıl sunulduğunun ve siyasi kutuplaşmanın haber metinlerinde nasıl gerçekleştiğinin araştııııması amaçlanmıştır. Kutuplaşmanın nedenlerine bakıldığında, Marksist bakış açısıyla, toplumların üretim ilişkileri ve bu ilişkilerdeki konumlanma sürecinden; yapısalıı bağlamda ise dil ve kültür gibi yapıların "ikili karşıtık" ilişkisinden hareketle kutuplaşmaların ortaya çıktığı söylenebilir. Kutuplaşmanın başlangıç noktası siyaset ve toplumsal alan olurken, medyanın kutuplaşan grupların konsolidasyonunu sağlama görevini yerine getirdiği görülmektedir. Bu çalışmada "ideolojik yönelim olarak görece merkez medya" konumundaki, ana akım ve alternatif medya olarak tanımlanabilecek iki farklı gazete incelenmiştir. Yapılan nicel ve nitel içerik analizi sonucunda, COVID-19'a ilişkin haberlerde, "yurttaşların sorumsuzluğu" ve "devlet yetkililerinin yetersizliği" ekseninde kurulan ikili karşıtlık olduğu görülmektedir. Bu durum, Türkiye'deki iktidar ve muhalefet kanadındaki aktörlerin argümanlarıyla uyumluluk taşımaktadır.

Ana akım ve alternatif medya arasında koronavirüs haberlerini ele alış şekli ve oranı, haber sayısı ve haberi sunduğu bağlam bakımından farklılıklar olduğu görülmektedir. Sürece ilişkin Gazete Pencere 162, Hürriyet ise 73 adet haber yapmıştır. Çalışmada uygulanan nicel içerik analizinden hareketle, hem alternatif hem de ana akım medyada yayımlanan COVID-19 haberlerinde, bilim insanlarına göre siyasi 
aktörlerin daha çok öne çıktığı saptanmıştır. Bu bulgu, Chinn vd.'nin (2020) ve Hart vd.'nin (2020) ABD'deki gazetelere ilişkin yaptığı çalışmanın sonuçlarıyla tutarlııı taşımaktadır. Çünkü, haber odası normlarındaki ön yargılar ve izleyicilerin dikkatini bir hikayeye çekme arzusu, içeriğin daha fazla siyasallaşmasına yol açabilmektedir (Hart, Chinn, \& Soroka, 2020, s. 4). Dolayısıyla, bilim insanlarına göre siyasi aktörlerin haberlerde daha fazla yer almasını sadece kutuplaşma ilişkisiyle değil, aynı zamanda liberal gazetecilik kodlarının sorgulanmasıyla da ilişkilendirmek önemlidir. İleride bu bağlamda kurulacak bir çalışma, haberdeki kutuplaşma konusuna farklı ve anlamlı bir açılım sunacaktır.

Çözümleme sonucunda iki gazetede de belirli oranda siyasallaşma ve kutuplaşma gerçekleştiği söylenebilir. Ancak, gazetelerin konuları sunduğu bağlam farklılık göstermektedir. Gazete Pencere, COVID-19'a ilişkin haberleri "Vaka ve ölüm sayılarının doğru verilmemesi" ve "Devlet yetkililerinin kısıtlamalara uymaması" gibi konular üzerinden çerçevelerken, Hürriyet gazetesinin ise konuları, yurttaşların sorumsuzluğunu merkeze çekerek- "tedbirlere uyulmaması" ekseninde çerçevelemiştir. Chinn vd.'nin (2020) ve Hart vd.'nin (2020) çalışmalarında haberlerdeki siyasi söylemlerin belirgin şekilde farklı olması nedeniyle haberlerin giderek kutuplaştığına vurgu yapılmaktadır. Bu durum, bu çalışmada incelenen gazetelerde de gözlenmekte ve gazetelerin çeşitli siyasi söylemleri taşıyarak kutuplaşmayı yeniden ürettiği görülmektedir.

Buna ek olarak, gazetelerdeki konuların ve konuya ilişkin aktörlerin dağııımına bakıldığında iki gazetenin de partizan bir doğrultuda hareket etmediği görülmektedir. Alternatif ve ana akım medya olarak ayrılmalarına rağmen, bu durumun gazetelerin ideolojik yönelim olarak "merkez medya" konumlarıyla tutarlıık taşıdığı söylenebilir. Ancak, yapılan nitel çözümleme sonucunda Hürriyet gazetesinin indirgemeci bir ideolojik söylem retoriğini daha ön plana çıkardığı görülmektedir. Gazete Pencere'nin alternatif medya konumu, konuları daha eleştirel bir perspektiften sunma farklılığını ortaya koymaktadır. Hem sağlık haberciliğinin ekonomi politiğini hem de alternatif medya ve ana akım medya arasındaki farkı işaret eden bu durum, politik ve toplumsal kutuplaşmanın haber metinlerindeki etkisini ve kutuplaşmanın nasıl yeniden üretildiğini anlama adına da önemlidir. Dolayısıyla bu konu bağlamında değerlendirildiğinde, ikili karşıtlıklar ekseninde kurulan haberlerin kutuplaşması -yapısalı perspektifin aksine- normatif olarak bir simbiyotik ilişki oluşturmamaktadır. Medya gruplarının ekonomi politik yapılarının, haber metinlerindeki kutuplaşmayı etkileyen ve yansıtan başat unsur olduğu söylenebilir. 
$\mathrm{Bu}$ araştırmanın tartışması, hangi gazetenin argümanlarının tutarlı ve doğru olduğunun sorgulanması değildir. Bu çalışmanın çıkış noktası, COVID-19 pandemisi gibi halk sağlığını doğrudan etkileyen bir meselenin çerçevesinin ne ölçüde siyasi argümanlarla kurulup kurulmadığının tartışımasıdır. Illgili metinlerdeki anlamların, izlerkitleyi ne ölçüde etkilediği, ileride yapılacak alımlama çalışmalarında daha net şekilde görülebilir. Ancak, bu çalışmanın kapsamı ve araştırma nesneleri özelinde değerlendirildiğinde politik ve toplumsal alandaki güç ve iktidar mücadelesinin -sağlık konusu merkezde olmasına ve gazetelerin görece merkez medya konumlarına rağmen- medya alanında da kendisini gösterdiği söylenebilir.

\section{EXTENDED ABSTRACT}

In 2020, the world faced an epidemic of COVID-19 (coronavirus), a new type of virus. After the World Health Organization (WHO) declared an emergency on January 30, 2020, WHO announced on March 11, 2020 that the epidemic was a pandemic. While COVID-19 has made significant risk in Turkey, the Turkish media has some news about coronavirus and the media presented the statements of official authorities to the public. However, "how to present" news on public health issues such as the coronavirus is an issue that needs to be addressed. Health news is a mass issue of public concern. Unlike daily routine news, it is expected to convey information that will concern the majority (Ögüt, 2013, s. 59). In this context, how and in what context both political actors and the media convey information about COVID-19 is an important issue. Topics concerning general public health, such as coronavirus-related issues, should not be presented from political engagements. From these points, the subject of this study is to what extent and how Turkish mainstream and alternative media presented coronavirus news in the context of political polarization.

Based on this aim, two newspapers, which differ both in terms of political economy and medium, and whose political orientations are considered to be relatively central, have been analyzed. Hürriyet which is defined as the "flagship" in the Turkish press (Özkır, 2013, s. 61) and has an important position in the mainstream media, was chosen as the firts research object. Gazete Pencere, an independent publication that can be defined as alternative media, was chosen as the second research object.

Quantitative and qualitative research methods were used in the study since the problem of this study is based on testing (describing) and understanding (interpreting). In this context, with the 
quantitative content analysis technique, the frequency and context (supportive, neutral, negative) of the coronavirus news on the first pages of newspapers were analyzed. In addition, news texts were analyzed with qualitative content analysis in the context of sentence structures and meaning in order to reach more holistic findings. Finally, it has been tried to explain to what extent and how newspapers contribute to political polarization in news texts.

Polarization, a concept attributed to the field of sociology and political science, has different meanings and positions depending on the discipline in which it is used. When evaluated in the context of political science, it is seen that the concept is used to "measure" divisions in politics. Therefore, when the concept of polarization is discussed through political science, the subject of the field is "political polarization" (Talisse, 2019, s. 98). Polarization, when evaluated from a sociological point of view, is defined as the tendency to concentrate on two opposite extremes observed in many different contexts. However, most sociological typologies are descriptions of situations with polar types or extremes (Marshall, 1999, s. 439).

Although they have different contexts, it can be said that there are "binary oppositions" at the basis of the phenomena that create polarization. Claude Lévi-Strauss (1995), one of the important thinkers of structural anthropology, uses the concept of "binary opposition" in explaining the structure of societies by applying the linguistic method to culture. However, it can be a reductionist approach to analyze each concept and phenomenon as "contrasts that complement each other" in a cultural or social context (Zizek, 2011, s. 43).

In the context of media and polarization, when the guiding effect of the media is considered from a critical point of view, it can be said that media texts are included in the dominant economic, social and political production relations in a society (Inal, 1996, s. 29) and in this sense they are the carriers of power and power relations (Vona Kurt, 2015, s. 194). Therefore, it can be stated that as a reflection of power and power relations in society, news topics are framed with binary oppositions, and in this way the "us" and "other" positions that a reflection of the cultural structure are legitimized.

Based on these concepts, quantitative and qualitative analysis has been applied to the news on COVID-19. As a result of the analysis, it is seen that there is a binary opposition which is established on 
the axis of "the irresponsibility of the citizens" and "the inadequacy of state officials". This situation of polarization is shown consistency with political actors' arguments in the ruling and opposition poles.

It appears that there are differences between mainstream and alternative media in terms of the number of coronavirus news and the context established by the news. Gazete Pencere published 162 news stories and Hürriyet published 73 news stories about coronavirus. Based on the quantitative content analysis, it was determined that political actors were more prominent than scientists in COVID19 news published in both alternative and mainstream media. It can be said that a certain degree of politicization and polarization took place in both newspapers. However, the context in which newspapers offer political actors has differed. While Gazete Pencere framed the coronavirus news on issues such as "not giving the correct number of cases and deaths" and "not complying with the restrictions of state officials", Hürriyet framed the issues on the axis of "citizens non-compliance with the measures".

In addition, considering the distribution of the topics and the actors related to the issue, it is seen that both newspapers do not act in a partisan direction. Although they are divided into alternative and mainstream media, it can be said that this situation is consistent with the "central media" positions of the newspapers as ideological orientation. However, as a result of qualitative content analysis, it is seen that Hürriyet produced reductionist rhetoric as an ideological discourse. While Gazete Pencere's independent alternative media position reveals the difference in presenting the issues from a more critical perspective; the political economy to which Hürriyet is affiliated, causes the newspaper to present its contents in a "reductionist" and in this context "legitimizing" presentation. This situation, which points to the difference between alternative media and mainstream media, is also important for understanding the impact of political and social polarization on news texts. Therefore, polarization of news based on binary oppositions - contrary to the structuralist perspective - does not normatively create a symbiotic relationship. It can be said that the political economy structures of media groups are the dominant element reflecting the polarization in news texts.

\section{KAYNAKÇA}

Adorno, T. (2016). Negatif diyalektik. (Ş. Öztürk, Çev.) İstanbul: Metis Yayınları.

Ağırdır, B. (2010). Siyasette ve toplumda kutuplaşma KONDA verileriyle kutuplaşmanın fotoğrafı. İstanbul: Konda Araştırma ve Danışmanlık. 
Aksoy, G., \& Nisan, F. (2001). Türkiye'deki terör olayları çerçevesinde Ankara patlamaları üzerine bir ççerik analizi çalışması. TRT Akademi, 2(3), 134-158.

Bauman, Z. (2012). Küreselleşme: Toplumsal sonuçları. (A. Yılmaz, Çev.) İstanbul: Ayrıntı Yayınları.

Benoit, W. (2010). Content analysis in political communication. E. Bucy, \& R. Holbert (Dü) içinde, Sourcebook for Political Communication Research (s. 268-278). New York and London: Routledge.

Berelson, B. (1952). Content analysis in communication research. Free Press.

Birsen, Ö., \& Öztürk, Ş. Y. (2011). Tüketim kültürü çerçevesinden sağlık haberleri. Akademik Bakış Dergisi, 26, 1-21.

Bolsen, T., Druckman, J., \& Cook, F. (2014). How frames can undermine support for scientific adaptations: Politicization and the status-quo bias. Public Opinion Quarterly, 78(1), 1-26.

Campante, F., \& Hojman, D. (2013). Media and polarization: Evidence from the introduction of broadcast TV in the United States. Journal of Public Economics, 100, 79-92.

Cangöz, i. (2015). Değişen anlam ve değerleriyle gazetecilik. Ankara: Sınırsız.

Carpini, M. (2004). Mediating democratic engagement: The impact of communicationson citizens involvement in political and civic life. L. Kaid (Dü.) içinde, Handbook of Political Communication Research (s. 413-452). London: Lawrence Erlbaum Associates Publishers.

Chinn, S., Hart, P., \& Soroka, S. (2020). Politicization and polarization in climate change news content, 1985-2017. Science Communication, 42(1), 112-129.

Dağtaş, E. (2006). Türkiye'de magazin basını. Ankara: Ütopya Yayınevi.

Druckman, J., Peterson, E., \& Slothuus, R. (2013). How elite partisan polarization affects public opinion formation. American Political Science Review, 107(1), 57-79.

Entman, R. (1993). Framing: Toward clarification of a fractured paradigm. Journal of Communication, 43(4), 51-58.

Fiske, J. (2003). Iletiş̧im çalışmalarına giriş. (S. İrvan, Çev.) Ankara: Bilim ve Sanat Yayınları.

Golding, P., \& Murdock, G. (1991). Culture, communications and political economy. J. Curran, \& M. Gurevitch (Dü) içinde, Mass Media and Society (s. 15-32). London: Edward Arnold.

Güdekli, A. (2016). Gündem belirleme kuramı bağlamında yazılı basın ile twitter gündeminin karşılaştırmalı analizi. Selçuk Üniversitesi Sosyal Bilimler Enstitüsü Dergisi, 35, 151-163.

Gür, E. G. (2009). Tüketim kültürü bağlamında sağılı haberleri. İstanbul: İstanbul Üniversitesi Sosyal Bilimler Enstitüsü, Yayınlanmamış Doktora Tezi.

Habermas, J. (2001). Iletişimsel eylem kuramı. 2.Cilt: Işlevselci aklın eleştirisi üzerine. (M. Tüzel, Çev.) İstanbul: Kabalcı Yayınevi.

Hart, P., Chinn, S., \& Soroka, S. (2020). Politicization and polarization in COVID-19 news coverage. Science Communication, 42(5), 679-697. 
Hodgetts, D., Chamberlain, K., Scammell, M., Karapu, R., \& Nikora, L. W. (2007). Constructing health news: Possibilities for a civic-oriented journalism. Health: An Interdisciplinary Journal for the Social Study of Health, Illness and Medicine, 12(1), $43-66$.

Huberman, A., \& Miles, M., B. (1994). Qualitative data analysis: An expanded sourcebook (2nd ed). London and New Delhi: SAGE Publication.

İnal, A. (1996). Haberi okumak. İstanbul: Temuçin Yayınları.

Kaye, J., \& Quinn, S. (2010). Funding journalism in the digital age: Business models, strategies, issues and trends. New York: Peter Lang.

Koçak, A., \& Arun, Ö. (2006). içerik analizi çalışmalarında örneklem sorunu. Selçuk iletişim Dergisi, 4(3), 21 28.

Koloğlu, O. (1992). Osmanlı'dan günümüze Türkiye'de basın. İstanbul: Illetişim Yayınları.

Levi-Strauss, C. (1994). Yaban düşünce. (T. Yücel, Çev.) İstanbul: Yapı Kredi Yayınları.

Lévi-Strauss, C. (1995). Irk, tarih ve kültür. (H. Bayrı, R. Erdem, A. Oyacıoğlu, \& I. Ergüden, Çev.) İstanbul: Metis Yayınları.

Li, Y. (2019). Contest over authority: Navigating native advertising's impacts on journalism autonomy. Journalism Studies, 20(4), 523-541.

Marcuse, H. (1974). Marxism and feminism. Women's Studies: An Interdisciplinary Journal, 2(3), 279-288.

Marshall, G. (1999). Sosyoloji sözlüğü. (O. Akınhay, \& D. Kömürcü, Çev.) Ankara: Bilim ve Sanat Yayınları.

Marx, K. (1979). Ekonomi politiğin eleştirisine katkı. (S. Belli, Çev.) Ankara: Sol Yayınları.

Mayring, P. (2004). Qualitative content analysis. F. Uwe, V. Ernst , \& I. Steinke (Dü) içinde, A Companion to Qualitative Research (s. 266-275). London-Thousand Oaks-New Delhi: SAGE Publications.

McCarty, N. (2019). Polarization: What everyone needs to know ${ }^{\circledR}$. New York: Oxford University Press.

Murdock, G., \& Golding, P. (1973). For a political economy af mass communications. Socialist Register, 10, 205-234.

Mutz, D. (2006). How the mass media divide us. P. Nivola, \& D. Brady (Dü) içinde, Red and Blue Nation? Characteristics and Causes of America's Polarized Politics. Washington, DC: Brookings Institution Press.

Nadler, A., \& Bauer, A. (2019). News on the right: Studying conservative news cultures. USA: Oxford University Press.

NewsLabTurkey. (2020). Yavuz Oğhan Gazete Pencere'yi anlatıyor. Eylül 30, 2020 tarihinde https://www.youtube.com/watch?v=8Z8A7gRgu2l\&ab_channel=NewsLabTurkey adresinden alındı

Öğüt, P. (2013). Türkiye'de sağlık haberciliğinin tarihsel gelişimi ve Hürriyet Gazetesi örneği. Eskişehir: Anadolu Üniversitesi Sosyal Bilimler Enstitüsü, Yayınlanmamış Doktora Tezi.

Özer, Ö. (2010). Liberal basın. İstanbul: Literatürk Yayınevi.

Özkır, Y. (2013). Hürriyet Gazetesi'nin kimliği. Iğdır University Journal of Social Sciences, 3, 45-70. 
Prior, M. (2013). Media and political polarization. Annual Review of Political Science, 16, 101-127.

Saussure, D. (1985). Genel dilbilim dersleri. (B. Vardar, Çev.) Ankara: Birey ve Toplum Yayınları.

Scheufele, D. (1999). Framing as a theory of media effects. Journal of Communication, 49(1), 103-122.

Sönmez, M. (2004). Filler ve çimenler: Medya ve finans sektöründe Doğan/Anti-Doğan savaşı. İstanbul: Illetişim Yayınları.

Sözcü. (2020). Fahrettin Koca: Birinci dalganın ikinci pikini yaşıyoruz. Eylül 26, 2020 tarihinde https://www.sozcu.com.tr/2020/saglik/fahrettin-koca-diyarbakirda-durum-kontrol-altinda6022353 adresinden alındı

Stroud, N. (2010). Polarization and partisan selective exposure. Journal of Communication, 60(3), 556-576.

Talisse, R. (2019). Overdoing democracy: Why we must put politics in its place. New York: Oxford University Press.

Taylan, A., \& Ünal, R. (2017). Ana akım medyada sansasyonel habercilik: Sağık iletişimi örneği. Atatürk Iletişim Dergisi, 14, 27-44.

Utma, S. (2017). Medyadaki sağlık haberlerini "doğru" okumak. The Journal of Academic Social Science Studies, 57, 597-605.

Uzun, R. (2014). Medya-siyaset ilişkileri: Türkiye'de savunucu gazetecilik olgusunun incelenmesi. Iletişim Kuram ve Araştırma Dergisi, 39, 129-147.

Ülken, H. (1969). Sosyoloji sözlüğ̈̈. İstanbul: Milli Eğitim Basımevi.

Vona Kurt, E. (2015). Medya ve kutuplaşma: Kutuplaşmanın medyaya yansımalarının, 'Gezi Parkı Eylemleri' üzerinden değerlendirilmesi. Toplum ve Demokrasi Dergisi, 9(19-20), 193-223.

Wayne, M. (2003). Marxism and media studies: Key concepts and contemporary trends. London, Sterling, Virginia: Pluto Press.

WHO. (2010). What is a pandemic? Mart 30, 2021 tarihinde https://www.who.int/csr/disease/swineflu/frequently_asked_questions/pandemic/en/ adresinden alındı

Yaylagül, L., \& Çiçek, C. (2012). 12 Haziran 2011 seçimlerinin gazetelerde sunumu. Erciyes iletişim Dergisi, 2(4), 2-22.

Yücel, O. (2020) \#Koronavirüs zaman çizelgesi: Ne zaman ortaya çıktı? Nasıl yayıldı? Önemli tarihler nelerdi? Eylül 9, 2020 tarihinde https://medyascope.tv/2020/04/05/koronavirus-zaman-cizelgesi-nezaman-ortaya-cikti-nasil-yayildi-onemli-tarihler-nelerdi/ adresinden alındı

Yüksel, E., Kaya, A. Y., Koçak, A., \& Aydın, S. (2010). Türkiye'de sağıık konulu yayınların analizi. Kurgu, 24(1), 17-43.

Zizek, S. (2011). İdeoloji hayaleti. Z. Slavoj (Dü.) içinde, ideolojiyi haritalamak (S. Kibar, Çev.) Ankara: Dipnot Yayınları. 